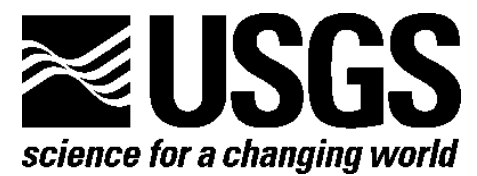

\title{
Geologic Framework for the National Assessment of Carbon Dioxide Storage Resources-Arkoma Basin, Kansas Basins, and Midcontinent Rift Basin Study Areas
}

By Marc L. Buursink, William H. Craddock, Madalyn S. Blondes, Philip A. Freeman, Steven M. Cahan, Christina A. DeVera, and Celeste D. Lohr

Chapter $\mathrm{F}$ of

Geologic Framework for the National Assessment of Carbon Dioxide Storage Resources

Edited by Peter D. Warwick and Margo D. Corum

Open-File Report 2012-1024-F 


\section{U.S. Department of the Interior \\ SALLY JEWELL, Secretary}

\section{U.S. Geological Survey \\ Suzette M. Kimball, Acting Director}

U.S. Geological Survey, Reston, Virginia: 2013

For product and ordering information:

World Wide Web: http://www.usgs.gov/pubprod

Telephone: 1-888-ASK-USGS

For more information on the USGS-the Federal source for science about the Earth,

its natural and living resources, natural hazards, and the environment:

World Wide Web: http://www.usgs.gov

Telephone: 1-888-ASK-USGS

Suggested citation:

Buursink, M.L., Craddock, W.H., Blondes, M.S., Freeman, P.A., Cahan, S.M., DeVera, C.A., and Lohr, C.D., 2013, Geologic framework for the national assessment of carbon dioxide storage resources-Arkoma Basin, Kansas basins, and Midcontinent Rift Basin, chap. F of Warwick, P.D., and Corum, M.D., eds., Geologic framework for the national assessment of carbon dioxide storage resources: U.S. Geological Survey Open-File Report 2012-1024-F, 35 p., http://dx.doi.org/10.3133/ofr20121024f.

ISSN 2331-1258 (online)

Any use of trade, product, or firm names is for descriptive purposes only and does not imply endorsement by the U.S. Government.

Although this report is in the public domain, permission must be secured from the individual copyright owners to reproduce any copyrighted material contained within this report. 


\title{
Editors' Preface
}

\author{
By Peter D. Warwick and Margo D. Corum
}

The 2007 Energy Independence and Security Act (Public Law 110-140) directs the U.S. Geological Survey (USGS) to conduct a national assessment of potential geologic storage resources for carbon dioxide $\left(\mathrm{CO}_{2}\right)$ and to consult with other Federal and State agencies to locate the pertinent geological data needed for the assessment. The geologic sequestration of $\mathrm{CO}_{2}$ is one possible way to mitigate its effects on climate change.

The methodology that is being used by the USGS for the assessment was described by Brennan and others (2010), who revised the methodology by Burruss and others (2009) according to comments from peer reviewers, members of the public, and experts on an external panel. The assessment methodology is non-economic and is intended to be used at regional to subbasinal scales.

The operational unit of the assessment is a storage assessment unit (SAU), composed of a porous storage formation with fluid flow and an overlying fine-grained sealing unit. Assessments are conducted at the SAU level and are aggregated to basinal and regional results. SAUs have a minimum depth of 3,000 feet (ft), which ensures that the $\mathrm{CO}_{2}$ is in a supercritical state (and thus occupies less pore space than a gas). Standard SAUs have a maximum depth of 13,000 ft below the surface, a depth accessible with average injection pipeline pressures (Burruss and others, 2009; Brennan and others, 2010). Where geologic conditions favor $\mathrm{CO}_{2}$ storage below 13,000 ft, an additional deep SAU is assessed.

The assessments are also constrained by the occurrence of relatively fresh formation water; any formation water having a salinity less than 10,000 parts per million (ppm, which is equivalent to milligrams per liter, mg/L) total dissolved solids (TDS), regardless of depth, has the potential to be used as a potable water supply (U.S. Environmental Protection Agency, 2009). The U.S. Environmental Protection Agency (2008) has proposed the limit of $10,000 \mathrm{ppm}(\mathrm{mg} / \mathrm{L}) \mathrm{TDS}$ for injection of $\mathrm{CO}_{2}$. Therefore, the potential storage resources for $\mathrm{CO}_{2}$ in formations where formation waters have salinities less than 10,000 ppm (mg/L) TDS are not assessed (Brennan and others, 2010).

This report series contains geologic descriptions of each SAU identified within the assessed basins and focuses on the particular characteristics specified in the methodology that influence the potential $\mathrm{CO}_{2}$ storage resource. Although assessment results are not contained in these chapters, the geologic framework information will be used to calculate a statistical Monte Carlo-based distribution of potential storage space in the various SAUs following Brennan and others (2010). Figures in this report series show SAU boundaries and cell maps of well penetrations through the sealing unit into the top of the storage formation. Cell maps show the number of penetrating wells within a quarter square mile and are derived from interpretations of incompletely attributed well data (IHS Energy Group, 2011; and other data as available), a digital compilation that is known not to include all drilling. The USGS does not expect to know the location of all wells and cannot guarantee the amount of drilling through specific formations in any given cell shown on cell maps.

\section{References Cited}

Brennan, S.T., Burruss, R.C., Merrill, M.D., Freeman, P.A., and Ruppert, L.F., 2010, A probabilistic assessment methodology for the evaluation of geologic carbon dioxide storage: U.S. Geological Survey Open-File Report 2010-1127, 31 p., accessed March 22, 2011, at http://pubs.usgs.gov/of/2010/1127/. 
Burruss, R.C., Brennan, S.T., Freeman, P.A., Merrill, M.D., Ruppert, L.F., Becker, M.F., Herkelrath, W.N., Kharaka, Y.K., Neuzil, C.E., Swanson, S.M., Cook, T.A., Klett, T.R., Nelson, P.H., and Schenk, C.J., 2009, Development of a probabilistic assessment methodology for evaluation of carbon dioxide storage: U.S. Geological Survey Open-File Report 2009-1035, 81 p., accessed March 22, 2011, at http://pubs.usgs.gov/of/2009/1035/.

IHS Energy Group, 2011, ENERDEQ U.S. well data: IHS Energy Group; online database available from IHS Energy Group, 15 Inverness Way East, D205, Englewood, CO 80112, U.S.A. (Accessed January 20, 2011).

U.S. Environmental Protection Agency, 2008, Federal requirements under the underground injection control (UIC) program for carbon dioxide $\left(\mathrm{CO}_{2}\right)$ geologic sequestration (GS) wells: Washington, D.C., U.S. Environmental Protection Agency, proposed rule, accessed March 23, 2011, at http://www.epa.gov/fedrgstr/EPA-WATER/2008/July/Day-25/w16626.htm.

U.S. Environmental Protection Agency, 2009, Safe Drinking Water Act (SDWA): Washington, D.C., U.S. Environmental Protection Agency Web site, accessed January 14, 2009, at http://www.epa.gov/ogwdw/sdwa/index.html. 


\section{Contents}

Editors' Preface

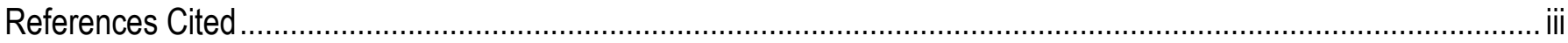

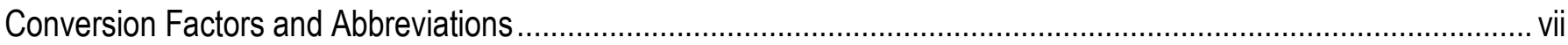

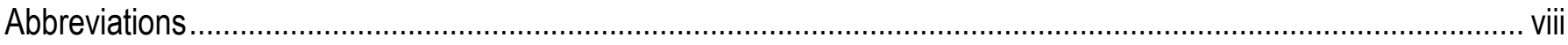

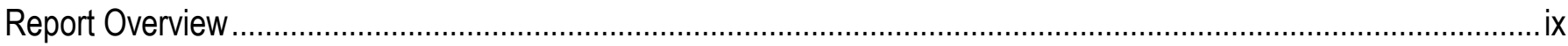

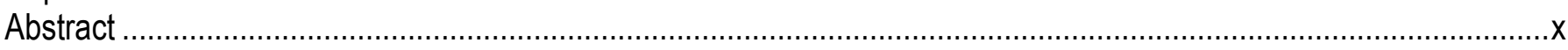

Geologic Framework for the National Assessment of Carbon Dioxide Storage Resources-Arkoma Basin ...... 1

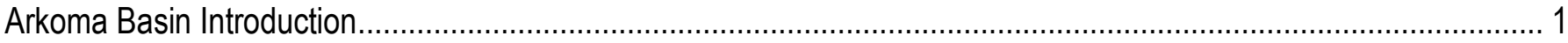

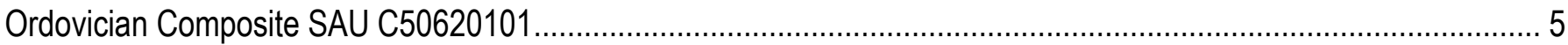

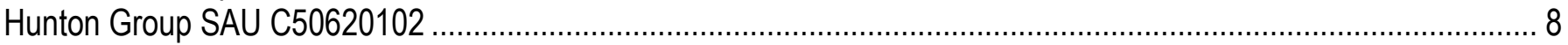

Batesville Sandstone and Wedington Sandstone Member SAU C50620103 ...................................................12

Geologic Framework for the National Assessment of Carbon Dioxide Storage Resources-Kansas Basins ...15

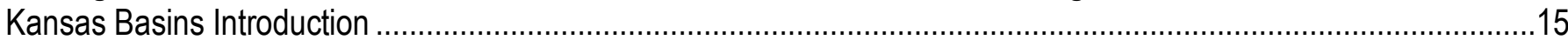

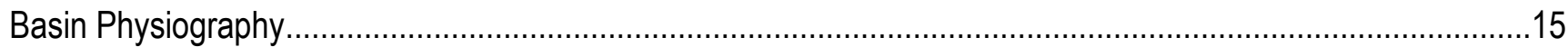

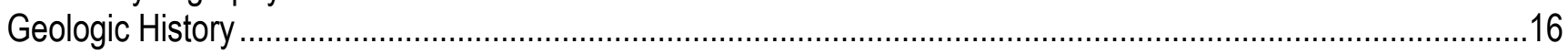

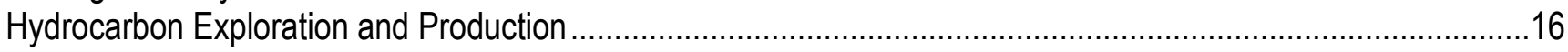

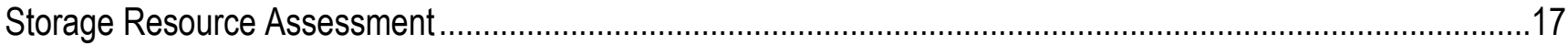

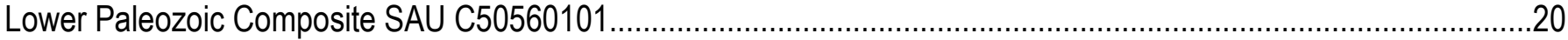

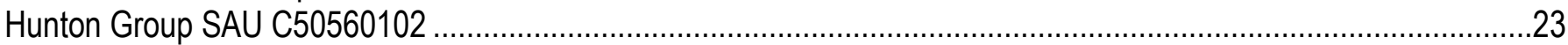

Geologic Framework for the National Assessment of Carbon Dioxide Storage Resources-Midcontinent

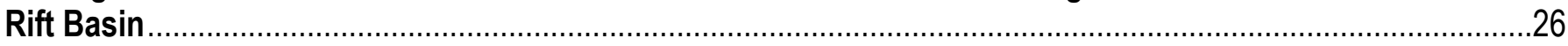

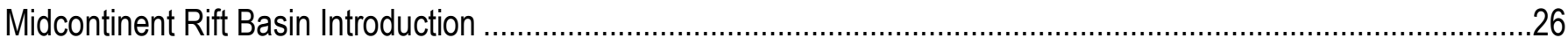

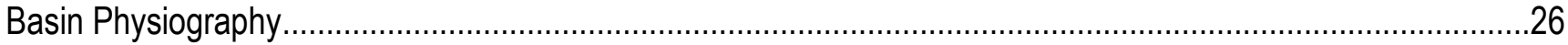

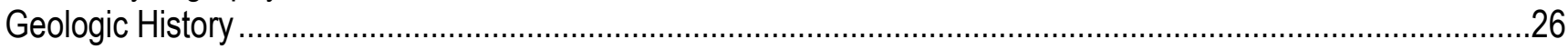

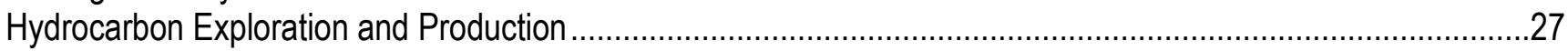

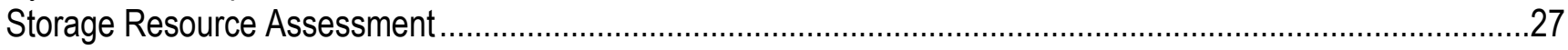

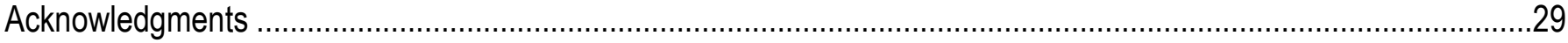

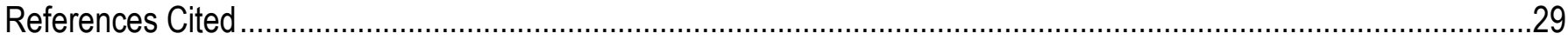




\section{Figures}

1. Map of the Arkoma Basin study area including major tectonic elements ......................................................... 3

2. Generalized stratigraphic column of geologic units in the Arkoma Basin study area .......................................... 4

3. Map of the Ordovician Composite Storage Assessment Unit (SAU) C50620101 in the

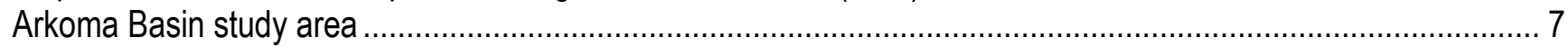

4. Map of the Hunton Group Storage Assessment Unit (SAU) C50620102 in the Arkoma Basin study area............ 11

5. Map of the Batesville Sandstone and Wedington Sandstone Member Storage Assessment Unit (SAU)

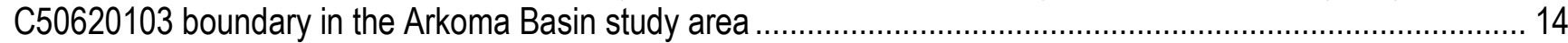

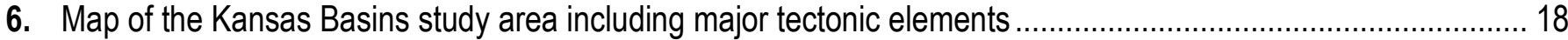

7. Generalized stratigraphic column of geologic units in Kansas Basins study area ............................................ 19

8. Map of the Lower Paleozoic Composite Storage Assessment Unit (SAU) C50560101 in the

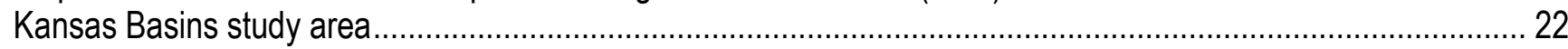

9. Map of the Hunton Group Storage Assessment Unit (SAU) C50560102 in the Kansas Basins study area .......... 25

10. Map of the Midcontinent Rift Basin study area including major tectonic elements .............................................. 28 


\section{Conversion Factors and Abbreviations}

\begin{tabular}{|c|c|c|}
\hline Multiply & By & To obtain \\
\hline \multicolumn{3}{|c|}{ Length } \\
\hline inch (in.) & 2.54 & centimeter $(\mathrm{cm})$ \\
\hline foot (ft) & 0.3048 & meter $(\mathrm{m})$ \\
\hline mile (mi) & 1.609 & kilometer $(\mathrm{km})$ \\
\hline \multicolumn{3}{|c|}{ Area } \\
\hline acre & 0.4047 & hectare (ha) \\
\hline acre & 0.004047 & square kilometer $\left(\mathrm{km}^{2}\right)$ \\
\hline square mile $\left(\mathrm{mi}^{2}\right)$ & & square kilometer $\left(\mathrm{km}^{2}\right)$ \\
\hline \multicolumn{3}{|c|}{ Volume } \\
\hline barrel (bbl), (petroleum, 1 barrel=42 gal) & 0.1590 & cubic meter $\left(\mathrm{m}^{3}\right)$ \\
\hline cubic foot $\left(\mathrm{ft}^{3}\right)$ & 0.02832 & cubic meter $\left(\mathrm{m}^{3}\right)$ \\
\hline 1,000 cubic feet (MCF) & 28.32 & cubic meter $\left(\mathrm{m}^{3}\right)$ \\
\hline liter (L) & 0.2642 & gallon (gal) \\
\hline
\end{tabular}




\section{Abbreviations}

$\begin{array}{ll}\mathrm{BBO} & \text { billion barrels of oil } \\ \mathrm{BCFG} & \text { billion cubic feet of gas } \\ \mathrm{CO}_{2} & \text { carbon dioxide } \\ \mathrm{MCRB} & \text { Midcontinent Rift Basin } \\ \mathrm{mD} & \text { millidarcy } \\ \mathrm{mg} / \mathrm{L} & \text { milligrams per liter } \\ \text { MMBO } & \text { million barrels of oil } \\ \text { MMBOE } & \text { million barrels of oil equivalent } \\ \text { NOGA } & \text { national oil and gas assessment } \\ \text { OFR } & \text { open-file report } \\ \text { ppm } & \text { parts per million } \\ \text { SAU } & \text { storage assessment unit } \\ \text { TCFG } & \text { trillion cubic feet of gas } \\ \text { TDS } & \text { total dissolved solids } \\ \text { USDW } & \text { underground source of drinking water } \\ \text { USGS } & \text { U.S. Geological Survey }\end{array}$




\section{Report Overview}

This three-part open file report (OFR) contains the geologic framework for three adjacent study areas, including the Arkoma Basin, multiple Kansas basins, and the Midcontinent Rift Basin (MCRB). Although these study areas are in close proximity and are included in a combined geologic framework OFR, the basins were formed and filled under different circumstances, and each is investigated and assessed separately. The Arkoma Basin is situated in central Arkansas and Oklahoma and contains a continuous succession of Paleozoic strata. It is overridden along its southern margin by the Ouachita orogenic belt, and it is bound to the north by two broad basement highs, the Ozark uplift in northern Arkansas and southern Missouri and the Cherokee platform in northeastern Oklahoma. The Kansas Basins study area includes the Salina and Sedgwick Basins, along with the Forest City Basin, Nemaha uplift, and Cherokee platform. The Salina Basin may be characterized as a simple asymmetric syncline with the basin deep along the southwestern flank adjacent to the Central Kansas uplift. The Sedgwick Basin is a broad south-plunging shallow embayment of the Anadarko Basin. Sections of the generalized stratigraphic columns for the Anadarko and Kansas Basins are similar, whereas the rocks and setting of the MCRB differs. The MCRB is a large, arcuate Mesoproterozoic rift zone, which extends from southeastern Ontario, Canada, to northern Michigan and terminates in northeast Kansas. As in previous OFR chapters of the National Assessment of Carbon Dioxide Storage Resources, geologists describe their investigation of the study areas and work on unique storage assessments units (SAUs). Furthermore, to preserve a consistent format across report chapters, these individual SAU descriptions are treated as toplevel sections. Lastly, each study area requires a separate introduction to develop the geologic assessment framework, as in prior OFR chapters. 


\section{Abstract}

The 2007 Energy Independence and Security Act (Public Law 110-140) directs the U.S. Geological Survey (USGS) to conduct a national assessment of potential geologic storage resources for carbon dioxide $\left(\mathrm{CO}_{2}\right)$. The methodology used by the USGS for the national $\mathrm{CO}_{2}$ assessment follows that of previous USGS work. This methodology is non-economic and intended to be used at regional to subbasinal scales.

This report identifies and contains geologic descriptions of three storage assessment units (SAUs) in Upper Cambrian to Mississippian sedimentary rocks within the Arkoma Basin study area, and two SAUs in Upper Cambrian to Mississippian sedimentary rocks within the Kansas Basins study area. The Arkoma Basin and Kansas Basins are adjacent with very similar geologic units; although the Kansas Basins area is larger, the Arkoma Basin is more structurally complex. The report focuses on the characteristics, specified in the methodology, that influence the potential $\mathrm{CO}_{2}$ storage resource in the SAUs. Specific descriptions of the SAU boundaries as well as their sealing and reservoir units are included. Properties for each SAU, such as depth to top, gross thickness, porosity, permeability, groundwater quality, and structural reservoir traps, are usually provided to illustrate geologic factors critical to the assessment. Although assessment results are not contained in this report, the geologic information herein was employed, as specified in the USGS methodology, to calculate a probabilistic distribution of potential storage resources in each SAU. The Midcontinent Rift Basin study area was evaluated, but not assessed, because no suitable storage formations meeting our size, depth, reservoir quality, and regional seal guidelines were found.

Figures in this report show study area boundaries along with the SAU boundaries and cell maps of well penetrations through sealing units into the top of the storage formations. The cell maps show the number of penetrating wells within one-square mile and are derived from interpretations of incompletely attributed well data and from a digital compilation that is known not to include all drilling. 


\section{Geologic Framework for the National Assessment of Carbon Dioxide Storage Resources-Arkoma Basin}

By William H. Craddock, Marc L. Buursink, Madalyn S. Blondes, Philip A. Freeman, Steven M. Cahan, and

Celeste D. Lohr

\section{Arkoma Basin Introduction}

Arkoma Basin, which is situated in central Arkansas and Oklahoma, contains a continuous succession of Paleozoic strata. It is overridden along its southern margin by the Ouachita orogenic belt, and it is bound to the north by two broad basement highs, the Ozark uplift in northern Arkansas and southern Missouri and the Cherokee platform in northeastern Oklahoma (fig. 1). The basin was part of a larger, south-facing (present-day coordinates) passive continental margin throughout most of the Paleozoic (Lowe, 1989), and many of the key physiographic boundaries were established during Pennsylvanian AppalachianOuachitan orogeny (Viele and Thomas, 1989). Arkoma Basin exhibits a typical foreland basin geometry, wherein stratal thicknesses diminish (or pinch out) toward northern basement highs and increase dramatically toward the Pennsylvanian Ouachita foredeep to the south (Nelson and others, 1982; Lillie and others, 1983; DeCelles and Giles, 1996; Ye and others, 1996; Miall, 2008). Whereas pre-Carboniferous strata attain a maximum thickness of around 10,000 feet (ft), the upper Paleozoic synorogenic strata may be in excess of 40,000 $\mathrm{ft}$ in the Ouachita foredeep in the southern part of the basin (Nelson and others, 1982; Lillie and others, 1983; Houseknecht, 1987). Formally, our study area includes Arkoma Basin, as well as a broad region extending to the south, which includes a portion of the Ouachita orogenic belt as well as a Permian successor basin that extends southward into the Louisiana-Texas border region (fig. 1) (Arkoma Basin Province Assessment Team, 2010). However, prospective rocks for carbon storage were only identified within the Arkoma Basin portion of the broader study area.

A synthesis of petroleum production in Arkoma Basin shows that it has a prolific history of oil and gas production. Known oil and gas reserves, which include produced and proven reserves, are greater than 288 million barrels of oil (MMBO) and greater than 23,346 billion cubic feet of gas (BCFG) (Nehring Associates, Inc., 2010). Moreover, the U.S. Geological Survey (USGS) estimates that about an additional $159 \mathrm{MMBO}$ and 38,021 BCFG remain undiscovered in the basin (Arkoma Basin Province Assessment Team, 2010). Although many of the estimated undiscovered resources are thought to be in continuoustype plays, the historically produced volume of hydrocarbons suggests that a large amount of pore space may be available for storage in both active and depleted hydrocarbon reservoirs.

The tectonic history of Arkoma Basin can be characterized as a transition from a rifted continental margin to foreland basin extending through the Paleozoic Era with an intervening passive margin phase (Houseknecht, 1986). The basin initiated during the breakup of the supercontinent Rodinia, and the conjugate margin is thought to be located in the modern Argentinian Precordillera (see Ramos and others, 1986; Thomas and Astini, 1999, and references therein). The precise timing of basin-initiation in Arkoma is controversial with some authors invoking a late Neoproterozoic age based on inferred continuity with the Appalachian margin to the east (present-day orientation; see Thomas, 1977; Lowe, 1989) and others invoking a Middle or Late Cambrian age based on the age of the oldest exposed sedimentary rocks in the region (Lowe, 1985, 1989). Following breakup, Arkoma Basin occupied part of a broad, south-facing passive continental margin extending from present-day Alabama to northeastern Mexico and adjoining an east-facing passive margin in the eastern United States and Canada (see Thomas, 1991; Thomas and 
Astini, 1999; Miall, 2008, and references therein). The basin remained in a passive margin setting throughout much of the Paleozoic, but eventually, from the Middle Mississippian to Middle Pennsylvanian, a series of island-arc terranes, and finally the Gondwanan continent, were sutured to the southern margin of North America during the assembly of the supercontinent Pangaea (Sutherland, 1988; Miall, 2008, and references therein). Sedimentary rocks in Arkoma Basin may be divided into four tectonostratigraphic units, which correspond to the basic stages of tectonic evolution (Houseknecht, 1986): (1) the basin is floored by Middle, or perhaps Upper, Cambrian and Lower Ordovician siliciclastics and carbonates that were deposited during continental breakup (fig. 2) (Lowe, 1989; Miall, 2008); (2) these basal strata are covered by Ordovician to Silurian platform carbonates and laterally equivalent basinal shales and sandstones (fig. 2) (Amsden, 1980; Lowe, 1989); (3) the various lower Paleozoic strata are overlain by Devonian and Lower Mississippian siliciclastics, which were generally deposited in a passive margin setting, although island arcs approached the southern continental margin at this time (fig. 2) (Sutherland, 1988; Lowe, 1989); and (4) the basin is capped by a thick succession of synorogenic flysch and molasse deposited during the Carboniferous Appalachian-Ouachitan orogeny (fig. 2) (Houseknecht, 1986; Sutherland, 1988; Ye and Kerr, 2000; Miall, 2008). Rather than reviewing the large number of formations that have been defined within the Carboniferous flysch succession in Arkoma Basin, we present a simplified stratigraphy wherein rocks of the Pennsylvanian System are subdivided into the Morrowan, Atokan, and Desmoinesian Provincial Series (fig. 2).

Three storage assessment units (SAUs) within the Arkoma Basin meet criteria for conducting a regional assessment for carbon dioxide $\left(\mathrm{CO}_{2}\right)$ storage capacity, as defined in Burruss and others (2009), Brennan and others (2010), and Blondes and others (2013). All three SAUs are in the middle part of the Paleozoic passive margin stratigraphic sequence. From oldest to youngest, the SAUs include (1) a composite of the various Ordovician carbonates, (2) a composite of the Silurian and Devonian Hunton Group and the overlying Devonian informal Misener sandstone, and (3) the Mississippian Batesville Sandstone and Wedington Sandstone Member of the Fayetteville Shale. Pennsylvanian synorogenic flysch deposits were not assessed despite the fact that this stratigraphic interval accounts for the vast majority of the overall hydrocarbon production in the basin (Boyd, 2002). Although there are thick accumulations of Pennsylvanian flysch in the foredeep position of the Arkoma Basin, we were unable to define lithostratigraphic units well enough to characterize regional reservoir and seal formations within this stratigraphic package. We must emphasize, however, that detailed site characterization may identify many highly prospective $\mathrm{CO}_{2}$ reservoirs within Pennsylvanian strata.

In the following sections, we characterize the distribution and stratigraphic character of each prospective SAU. We briefly summarize the key information that provides the basis for calculating the capacity of each of the SAUs for buoyant and residual $\mathrm{CO}_{2}$ storage (as described in Burruss and others, 2009; Brennan and others, 2010; Blondes and others, 2013; a function of SAU area, thickness, and porosity) as well as information that relates to the reservoir characteristics for each unit. Due to the fact that the U.S. Environmental Protection Agency $(2009,2010)$ stipulates that aquifers must contain groundwater with a total dissolved solids (TDS) concentration greater than 10,000 milligrams per liter (mg/L) in order to be used for $\mathrm{CO}_{2}$ storage, we characterize regional trends in groundwater quality. Finally, we defined the portion of the overall pore volume that may be contained within buoyant traps (terminology from Brennan and others, 2010) for the various SAUs that are analogous to stratigraphic and (or) structural hydrocarbon traps. For each SAU, the minimum and most likely pore volumes enclosed within buoyant traps were constrained on the basis of (1) the sum of the cumulative oil and gas production and the known hydrocarbon reserve volume and (2) the minimum buoyant volume plus the estimated volume of undiscovered resources (see Brennan and others, 2010). Due to the fact that this method was applied to all SAUs, it is not discussed on a case-by-case basis. An upper bound for enclosed pore volume was also determined for each unit, and we describe our methods for the various SAUs on a case-by-case basis. The information derived from the data sources and methods described herein will be used in accordance with the USGS Carbon Sequestration Assessment Methodology (Burruss and others, 2009; Brennan and others, 2010; Blondes and others, 2013) to calculate the available storage space for $\mathrm{CO}_{2}$ within the SAU. 


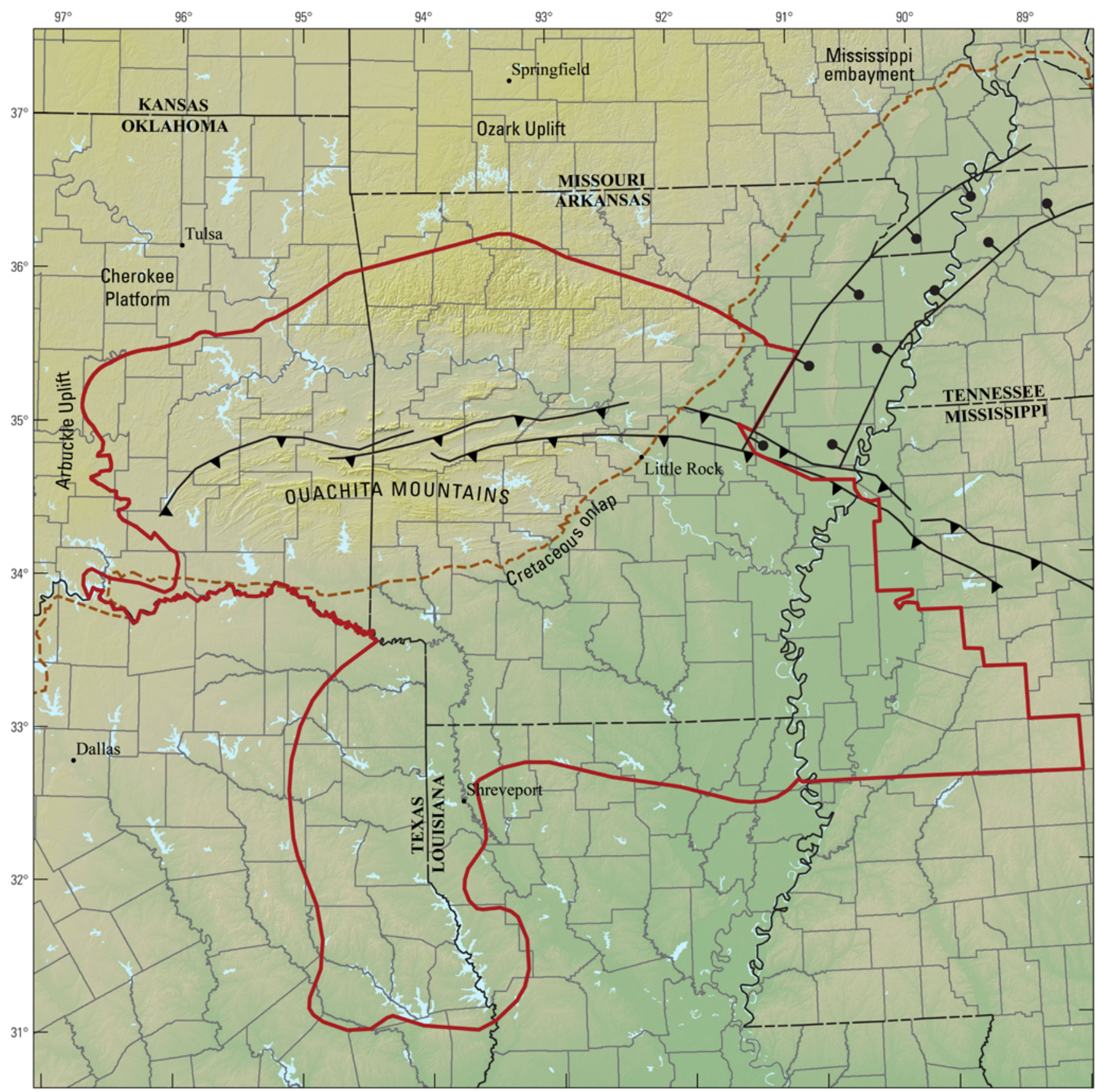

Elevation from U.S. Geological Survey National Elevation Dataset digital elevation model, 2009, 90-meter resolution

Albers Equal Area Projection

Central meridian $95^{\circ} 00 \mathrm{~W}$
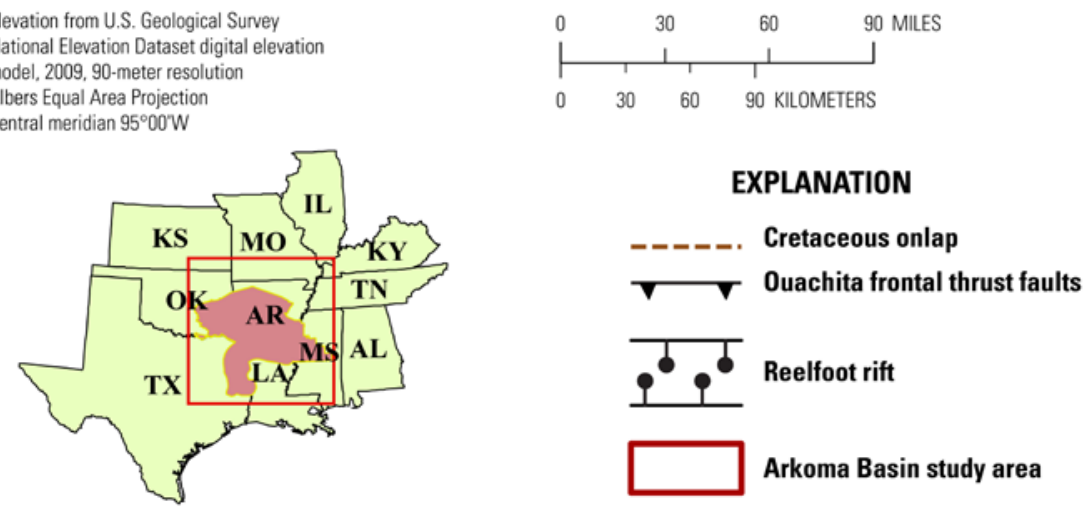

Figure 1. Map of the Arkoma Basin study area including major tectonic elements (adapted from Arkoma Basin Province Assessment Team, 2010). 


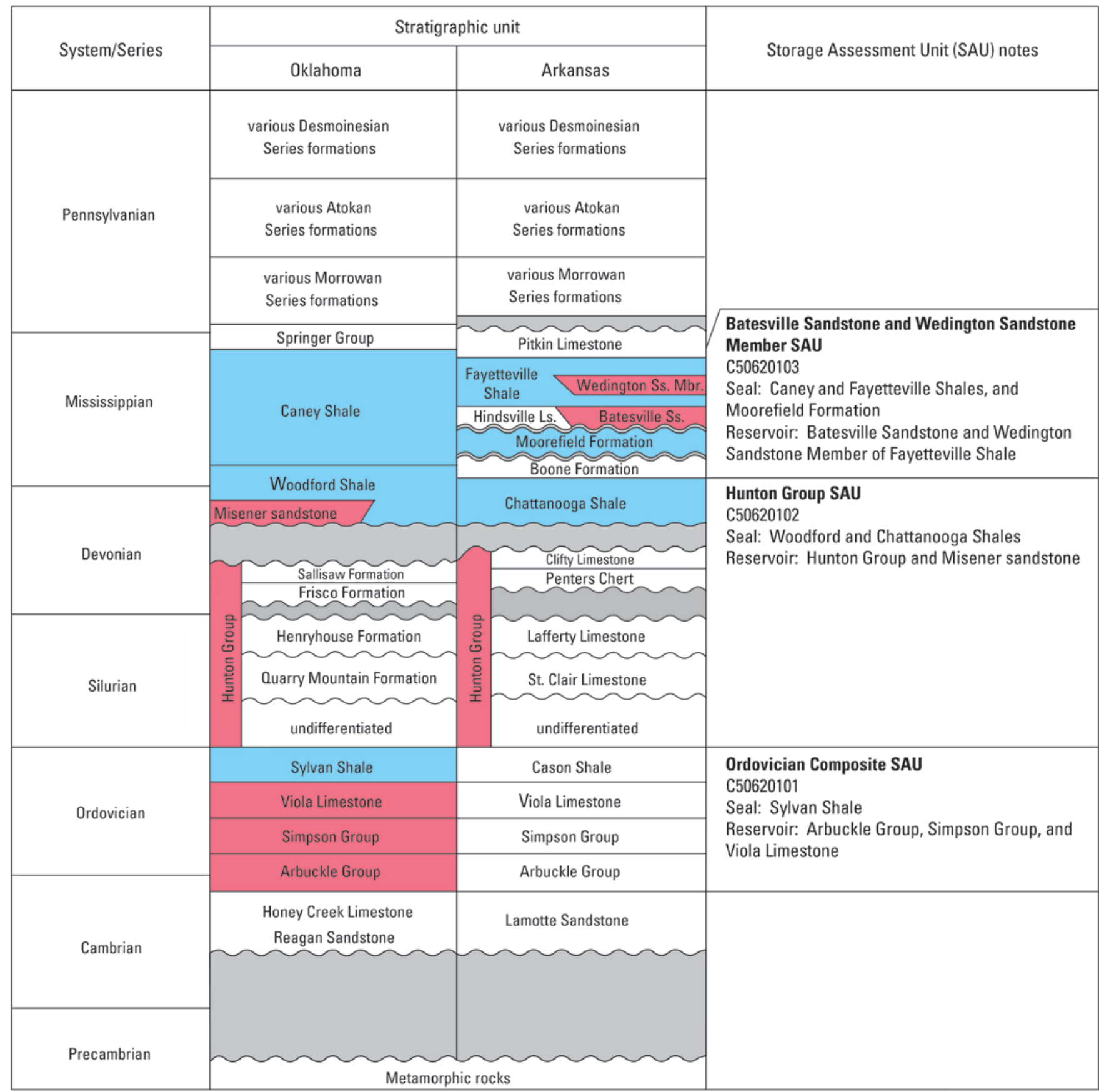

Figure 2. Generalized stratigraphic column of geologic units in the Arkoma Basin study area (adapted from Perry, 1995; Sutherland, 1988; and Fritz and Medlock, 1994). Storage assessment units (SAUs) consist of a reservoir (red) and a regional seal (blue). Wavy lines indicate unconformable contacts, and gray sections represent unconformities or hiatuses. In some cases, subdivisions of units or lesser known correlative units are not shown. Ss., Sandstone; Ls., Limestone; Mbr., Member. 


\title{
Ordovician Composite SAU C50620101
}

\author{
By Marc L. Buursink
}

The Ordovician Composite SAU consists of those portions of the preserved siliciclastic and carbonate lithology deemed suitable as reservoirs for $\mathrm{CO}_{2}$ storage and occurring beneath a regionally extensive seal limited to the Arkoma Basin in Oklahoma. The Arbuckle Group, Simpson Group, and Viola Limestone make up this composite SAU (figs. 2 and 3). The Upper Cambrian and Lower Ordovician Arbuckle Group comprises thick, almost pure carbonate successions that are often dolomitized from subaerial and subsurface diagenesis with permeability enhanced by fracturing and karstification (Henry and Hester, 1995; Johnson and Merriam, 2001). A relatively large carbonate platform with cyclical sea-level variation was the depositional setting for the Arbuckle Group (Johnson and Merriam, 2001). The Middle Ordovician Simpson Group comprises sandstone, interbedded shale, and carbonate beds occurring above Arbuckle rocks and beneath Viola Limestone, which are separated from the Simpson by minor unconformities (Cole, 1975; Lee and others, 1946; Taff, 1902). The Simpson Group sandstones are unique in this otherwise carbonate and shale dominated section, and their deposition was complicated through changes in subsidence rate, quartz sand supply, and regional tectonics (Henry and Hester, 1995; Johnson, 1997). The Upper Ordovician Viola Limestone is a massive white and bluish limestone with concretions in the lower and middle sections (Taff, 1902). Self-sourced hydrocarbons are produced from both fracture porosity and primary porosity zones in the Viola Limestone (Evans, 1984; Henry and Hester, 1995). The Sylvan Shale overlies the Viola Limestone and functions as the regionally thick sealing formation (Adler and others, 1971; Henry and Hester, 1995; IHS Energy Group, 2010) (fig. 2). The Upper Ordovician Sylvan Shale of Oklahoma is laterally equivalent to the Cason Shale of Arkansas, where it is thinner (Perry, 1995). These shales were deposited in relatively deep and calm waters (Blakey, 2011; Johnson, 1997; Ham, 1973). Regionally the Sylvan Shale is a soft, green, fissile shale that forms swales between the Viola Limestone and overlying Hunton Group limestones (Taff, 1902; Adler and others, 1971). Ultimately, the SAU was limited to the Arkoma Basin in Oklahoma because the minimum seal-thickness requirement of this assessment is met only in this part of the study area.

The composite SAU boundaries are defined by the depth below the surface of the uppermost storage formation. Here formation picks, reported in a commercial database (IHS Energy Group, 2010), for the Viola Limestone help define the top of the storage interval. The Ordovician Composite SAU C50620101 sits between 3,000 and 13,000 ft in depth and has a most likely area of about 2,297,000 acres (fig. 3). These interpretations are supported by the cross sections and isopach maps from Adler and others (1971). Analyses of the stratigraphy, net-to-gross ratio, and net-porous intervals for the three storage formations within the composite SAU were obtained mainly from Mairs (1966) and Ramondetta (1990) for the Viola Limestone, from Statler (1965) and Holden (1965) for the Simpson Group, and from Latham (1968) and Ching and Friedman (2000) for the Arbuckle Group. The Ordovician Composite SAU gross thickness ranges between 3,500 and 6,000 ft with a net thickness between 800 and 1,400 ft.

The Ordovician rocks are a productive hydrocarbon interval in the Arkoma Basin, and reservoirquality data is reported in multiple forms. Besides published porosity values (Ramondetta, 1990; Sykes, 1997) and permeability values (Read and Richmond, 1993; Carr and others, 2005), additional average field values were obtained from Nehring Associates, Inc. (2010), a commercial oil and gas database. The Ordovician Composite SAU porosity ranges between 5 and 15 percent, and permeability ranges between 0.001 and 1,000 millidarcies $(\mathrm{mD})$. 
In addition to the storage-formation thicknesses and reservoir quality, the groundwater quality was investigated and buoyant storage was assessed. Water-quality data obtained for the SAU area from published databases and tables (Carr and others, 2005; Breit, 2002; Carr and others, 1986) indicated saline groundwater. Therefore, the entire area of the SAU was assessed to have a groundwater TDS value greater than the U.S. Environmental Protection Agency $(2009,2010)$ underground source of drinking water (USDW) limit of 10,000 mg/L. To create a probabilistic maximum volume for buoyant trapping for each SAU, both the size and location of hydrocarbon plays (Arkoma Basin Province Assessment Team, 2010; Perry, 1995), along with the Nehring Associates, Inc. (2010) average field size and location, were used. 


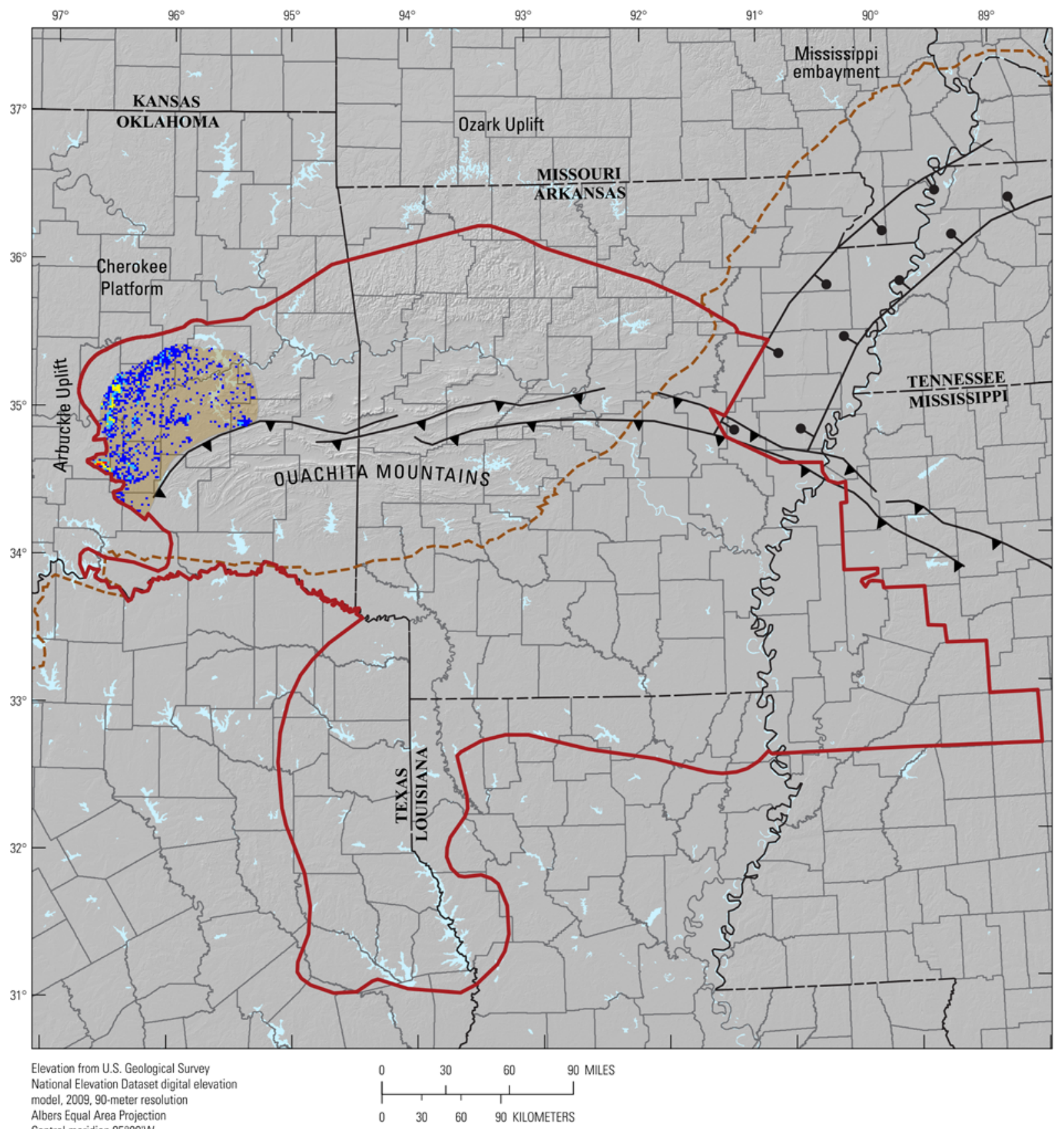

Central meridian 9500'w
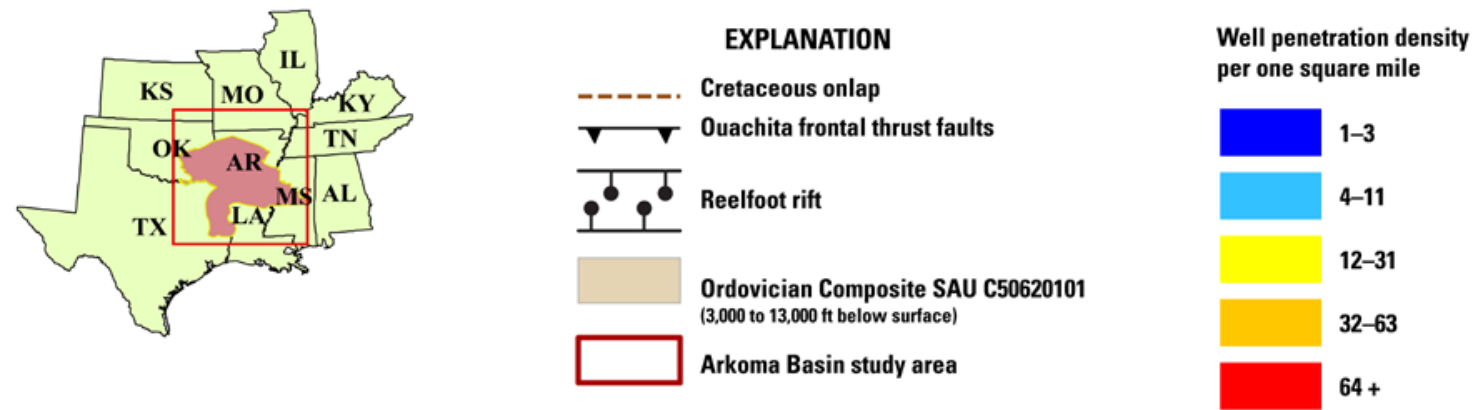

Figure 3. Map of the Ordovician Composite Storage Assessment Unit (SAU) C50620101 in the Arkoma Basin study area. Grid cells (one-square mile) display counts of wells derived from the IHS Energy Group (2011) well database that have penetrated the storage-formation top. Study area adapted from the Arkoma Basin Province Assessment Team (2010). 


\title{
Hunton Group SAU C50620102
}

\author{
By William H. Craddock
}

The Hunton Group (fig. 2) is a succession of carbonates that was deposited across the southern midcontinent region during the Silurian and Early Devonian (Amsden, 1949, 1951, 1958a,b). Paleogeographic reconstructions suggest that modern Arkoma Basin was located updip of the continental shelf edge of the Silurian and Devonian passive southern continental margin (Fritz and Medlock, 1994) such that the Hunton Group was deposited in a shelfal setting. Interpretation of geophysical logs from several transects across the Arkoma Basin region, as well as outcrop studies from the Cherokee platform, suggest that facies represented within the Hunton Group include supratidal carbonate mudstones, intertidal mudstones and skeletal wackestones, and subtidal wackestones, packstones, and mudstones (England, 1964; Fritz and Medlock, 1994; Rechlin, 2005). In general, the water depth of Hunton Group strata increases to the south, across the Arkoma Basin (Fritz and Medlock, 1994), toward the SilurianDevonian continental shelf margin. The Hunton Group is unconformably overlain by the informal Devonian Misener sandstone, which is thought to be an incised valley-fill deposit related to the early stages of a major eustatic transgression in the Middle Devonian (where present in Arkansas, this unit is referred to as the Sylamore Sandstone) (Amsden and Klapper, 1972; Kuykendall and Fritz, 2001). The Hunton and Misener interval is in turn overlain by a thick stratigraphic succession dominated by shales that accumulated in an open-marine setting during Devonian and Mississippian. These Devonian and Mississippian shales include the Woodford, Chattanooga, Caney, and Fayetteville Shales, and the Moorefield Formation shales (see Huffman, 1959; Sutherland, 1988; Handford, 1995; Perry, 1995). Inspection of a basin-wide network of geophysical logs indicates that, in aggregate, these rocks are hundreds of feet thick across the entire Arkoma Basin region and may be greater than 1,000 ft below the Cretaceous and Tertiary fill of the Mississippi embayment. As such, the Devonian and Mississippian stratigraphic interval may constitute an excellent topseal for $\mathrm{CO}_{2}$ containment. Recent hydrocarbon exploration in the Devonian and Mississippian shales has been accompanied by hydraulic fracturing of these units, including the Woodford and the Fayetteville in Arkoma Basin. On a local scale, this activity may have the potential to compromise topseal quality.

The SAU boundaries are defined by the 3,000- and 13,000-ft overburden contours determined from a network of borehole penetrations of the Hunton Group and (or) the Misener sandstone (IHS Energy Group, 2010) and the Ouachita thrust-fault network along the southern basin margin (fig. 4). The SAU covers an area of 7,704,000 acres ( \pm 10 percent), and the mean reservoir depth within this broad SAU is about $8,000 \mathrm{ft}$. Along the southern basin margin, there are several 3- to 5-mile- (mi-) wide swaths of rock adjacent to the Ouachita fault network, which are buried to depths greater than 13,000 ft. These regions were not included in our SAU (see Brennan and others, 2010). We extended the boundary of this SAU eastward to the edge of the Reelfoot rift (fig. 1) for a variety of reasons. First, Misener sandstone incised valley-fill deposits are thought to exist as far east as the Reelfoot rift (Kuykendall and Fritz, 2001), and although there is little to no historical petroleum production across this region (Boyd, 2002), reservoir-quality sandstones may exist. Moreover, Hunton Group carbonates share a common marineshelf depositional setting (Fritz and Medlock, 1994) and structural history across the Arkoma region, such that there is a possibility of similar primary, secondary, and (or) fracture porosity in Hunton Group rocks in Arkansas as compared to Oklahoma, despite the lack of historical petroleum production (Kunsman, 1967). We note that some east-west changes in depositional setting within the Hunton Group are probable, as indicated by the apparent lateral equivalence between the Sallisaw or Frisco Formations and the Penters Chert (Fritz and Medlock, 1994). 
The Hunton Group consists of several geologic formation-rank units (see Jones, 1960; Amsden, 1980; Campbell, 1993; and Northcutt, 1993, for details of Hunton Group stratigraphy). The group is thickest within a depocenter in central Arkansas, in the central part of Arkoma Basin, and generally thins to the west, north, and northeast (Rascoe and Hyne, 1987). The unit pinches out near the northern margin of Arkoma Basin. The unit is also eroded above the Arbuckle Mountain uplift in the southeastern corner of Arkoma Basin. Furthermore, in many places, the Hunton Group is entirely excised below the contact with the Devonian shale units which are the seal for the SAU (Shannon, 1962; Rascoe and Hyne, 1987). Based on a regional compilation of isopachs for the Hunton Group (Rascoe and Hyne, 1987), we estimate that the average gross thickness of the Hunton Group across the SAU is $270 \pm 50 \mathrm{ft}$.

Due to a paucity of published reservoir information about the Hunton in the Arkoma Basin, it is difficult to constrain the net-porous thickness on a regional level. Two intervals within the Hunton that may be relatively porous regionally are the Devonian Sallisaw Formation and the Silurian St. Clair (also called Clarita) Limestone and Quarry Mountain Formation (fig. 2) (Fritz and Medlock, 1994). These intervals appear to be the most common zones of hydrocarbon production within the Hunton Group (Nehring Associates, Inc., 2010). The Sallisaw and equivalents may be separated from the St. Clair Limestone and the Quarry Mountain Formation by a zone of tight carbonate (Fritz and Medlock, 1994). Parts of the Hunton Group are erosionally truncated, adding to the complication of estimating the regional mean stratigraphic thickness (Shannon, 1962). Based on inspection of regional subsurface correlations of borehole data, however, we estimate that the Hunton Group may contain on the order of 10 to $20 \mathrm{ft}$ of porous rock, on average, across the region.

The Misener sandstone produces oil and gas from conventional reservoirs around the midcontinent region, so we also augment the gross and net thickness of the Sallisaw reservoir interval by that of the overlying Misener. Locally, the Misener sandstone may approach $100 \mathrm{ft}$ in thickness (Amsden and Klapper, 1972; Kuykendall and Fritz, 2001), but most commonly it is a few to a few tens of feet thick where it has been penetrated in boreholes (Amsden and Klapper, 1972; Kuykendall and Fritz, 2001; Rechlin, 2005). Moreover, the Misener sandstone is restricted to incised valleys separated by interfluvial areas of nondeposition (Kuykendall and Fritz, 2001). We estimate that across the SAU, the Misener sandstone is on the order of 10 to $20 \mathrm{ft}$ thick, which slightly increases the gross thickness of the composite reservoir interval (Amsden and Klapper, 1972). At the scale of the entire Arkoma Basin, we estimate that the Hunton Group and Misener sandstone composite-reservoir interval contains a combined average of about 20 to $40 \mathrm{ft}$ of net-porous reservoir rock.

In general, the porosity of the potential reservoir rocks appears to be relatively low and spatially heterogeneous. The Sallisaw Formation, for example, exhibits a combination of intercrystalline and vuggy porosity, and it also exhibits significant fracture porosity, particularly where strata have been faulted or folded (Kunsman, 1967). Average porosity for five Hunton Group reservoirs in Arkoma, distributed across the north-central part of Arkoma Basin, is about 12 percent with individual measurements ranging from 10 to 15 percent (Campbell, 1993). Because so few porosity measurements are available for Hunton Group reservoirs in Arkoma Basin, we also examined porosity values from the closest correlative strata that we could find, which were in the adjacent Anadarko Basin, despite the potential for differing diagenetic histories between the two basins. Measurements from six fields in the Anadarko Basin suggest that porosity ranges from 3 to 11 percent (Northcutt, 1993). The porosity of the Misener sandstone appears to be slightly greater. Although we were not able to find measurements of Misener sandstone porosity within Arkoma, porosity from 12 fields on the Cherokee platform, to the northwest of Arkoma Basin, ranges from 8 to 14 percent (Busanus, 1987). This is broadly consistent with measurements from the Misener sandstone in central Kansas where porosity in a Misener oil field is about $10 \pm 4$ percent (Newell and others, 2001). In light of all of this information, we estimate that about $7 \pm 3$ percent is the average porosity of the composite Hunton-Misener reservoir unit across the SAU area.

No permeability measurements could be found for the Hunton or the Misener in Arkoma Basin, so again, we employed correlative rocks as analogs. Based on permeability measurements from other Paleozoic carbonate reservoir rocks around the United States (Nehring Associates, Inc., 2010), we assume 
that a reasonable lower limit on permeability for the Sallisaw is about $0.01 \mathrm{mD}$ and that this is a lower limit on permeability for the composite reservoir interval. In neighboring Anadarko Basin, permeability of the Hunton Group appears to be relatively low, and measurements from the petroleum fields described above range from 1 to $20 \mathrm{mD}$ with a modal value of about $5 \mathrm{mD}$ (Northcutt, 1993). This modal permeability appears to be fairly similar to measurements from the Misener sandstone from central Kansas (Newell and others, 2001), so we suggest that $5 \mathrm{mD}$ approximately describes the most likely permeability of this composite reservoir interval. Although Hunton Group reservoirs seem to be characterized by permeability values of no more than about $20 \mathrm{mD}$, the Misener exhibits permeability of up to about $200 \mathrm{mD}$ in central Kansas (Newell and others, 2001), and we use this as an upper limit on permeability of the reservoir interval. We note that highly fractured reservoirs could have permeability significantly higher than the range of values we reported above.

The salinity of formation waters within the Hunton Group has been measured at a few locations across Arkoma Basin, and the waters are uniformly characterized by TDS concentrations of greater than $100,000 \mathrm{mg} / \mathrm{L}$ (Breit, 2002). This is similar to measurements for overlying and underlying formations, and the extremely high salinity of formation waters within the lower Paleozoic section suggests that deeper formations of the Arkoma Basin may be relatively good intervals to dispose of $\mathrm{CO}_{2}$ without any risk of contaminating potential underground drinking-water sources.

The maximum pore volume available for buoyant storage was determined by multiplying the area of structural and (or) stratigraphic enclosure by upper bounds on the basin-averaged net-sand thickness and porosity (the last two parameters are described above). Oil accumulations in the Hunton Group are found in a combination of structural- and stratigraphic-type traps (Northcutt, 1993; Nehring Associates, Inc., 2010), and most oil fields are confined to the western part of the basin (Nehring Associates, Inc., 2010). In order to estimate the total closure area within the Hunton Group, we consulted maps of petroleum field distribution for the western half of the basin (Boyd, 2002). Although there appears to be no production from Silurian or Lower Devonian strata in the eastern part of the basin, we inferred that a similar closure area might exist within multiple, uncharged traps based on the trap distribution in Oklahoma and increased the maximum closure area accordingly. 


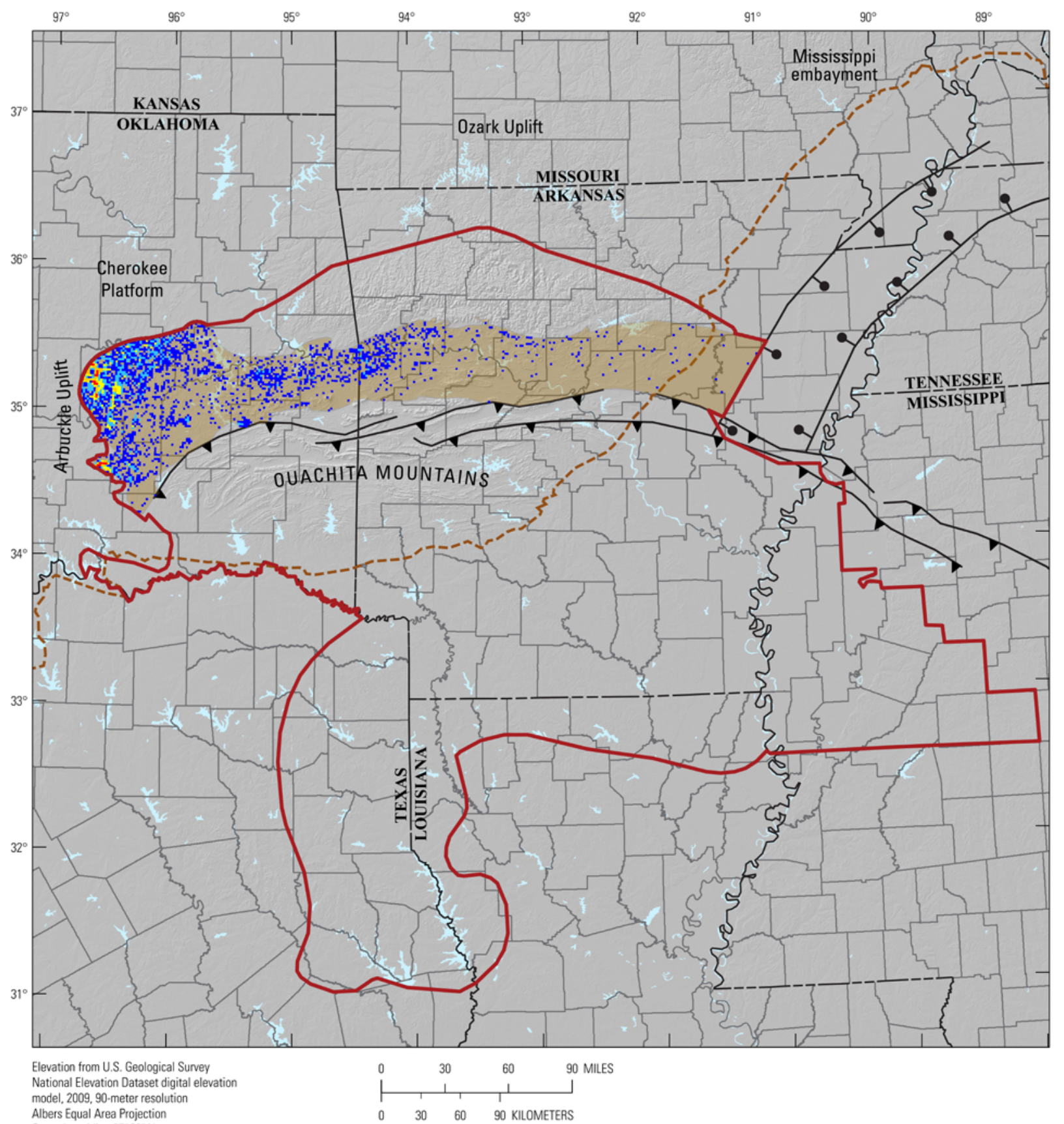

Albers Equal Area Projection

Central meridian $95^{\circ} 00^{\prime} \mathrm{W}$
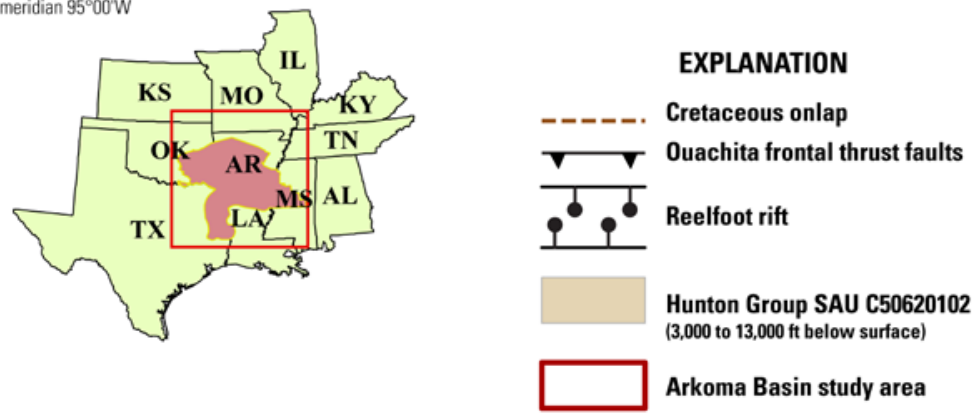

Well penetration density

per one square mile

1-3

4-11

12-31

$32-63$

$64+$

Figure 4. Map of the Hunton Group Storage Assessment Unit (SAU) C50620102 in the Arkoma Basin study area. Grid cells (one-square mile) display counts of wells derived from the IHS Energy Group (2011) well database that have penetrated the storage-formation top. Study area adapted from the Arkoma Basin Province Assessment Team (2010). 


\title{
Batesville Sandstone and Wedington Sandstone Member SAU C50620103
}

\author{
By William H. Craddock
}

The Batesville Sandstone and the Wedington Sandstone Member of Fayetteville Shale (fig. 2) are sandstone lenses that are interbedded with the Mississippian Fayetteville and Caney Shales of Arkoma Basin. The Batesville Sandstone was deposited within a broad, delta complex that originated along the northeastern margin of Arkoma Basin and prograded south and west across a continental shelf that occupied much of present-day Arkoma Basin (Sutherland, 1988; Handford, 1995). Specific depositional environments represented in the Batesville include wave-dominated delta-front and shoreface (Handford, 1995). Although the overlying Wedington Sandstone Member of Fayetteville Shale is poorly described in the literature, it is also thought to be a deltaic deposit, and regional patterns in Wedington thickness (increasing to the east) suggest that it also originated from a source along the northeastern margin of Arkoma Basin (Fabian, 1984; Sutherland, 1988). The encasing shales were deposited in an openmarine/prodeltaic setting (Ogren, 1968; Handford, 1995), and inspection of a regional network of well logs suggests that the Fayetteville-Caney interval is several hundreds of feet thick across the Arkoma region. These thick, open-marine shales should form robust topseals for the intercalated sandstone lenses. Recent hydrocarbon exploration in the Devonian and Mississippian shales in the southern midcontinent region has been accompanied by hydraulic fracturing of these units, including Fayetteville and Caney Shales in Arkoma. At least on a local scale, this activity may have the potential to compromise the quality of the seal.

SAU boundaries for the units are defined by the 3,000- and 13,000-ft overburden contours, the depositional limits of sandstones of Batesville and Wedington, and the Ouachita thrust-fault network along the southern basin margin (fig. 5). The SAU covers an area of about 1,781,000 acres, and the mean depth of the reservoir interval across this broad area appears to be about 9,000 ft. Overburden contours were built based on data from a regional network of borehole penetrations (IHS Energy Group, 2010), and the updip northern SAU limit follows the 3,000-ft overburden contour. The limit of sandstone in the Batesville and Wedington was based on regional correlation of well logs as well as formation tops in a proprietary well database (IHS Energy Group, 2010). In general, sandstone pinchouts define the eastern and western edges of the SAU. Importantly, most penetrations of the Batesville and the Wedington appear to be updip and north of the 3,000-ft contour; however, analysis of well logs indicates the potential for Batesville and Wedington sandstones to extend into the central and southern portion of the SAU. The western edge of the SAU also corresponds to an area where the gross thickness of the reservoir-seal interval is below $100 \mathrm{ft}$, such that topseals, particularly for the Wedington Sandstone Member, may be thin. We note the possibility that a Mississippian continental shelf margin may have crossed some portion of the SAU, such that there is a risk of major changes in reservoir stratigraphy across the southern portion of the SAU from shallow marine, continental shelf strata to continental shelf or basin-floor strata. Because any potential continental shelf margin is poorly defined, the southern SAU boundary generally corresponds to the Ross Creek thrust, a major thrust fault that defines the northern edge of the Ouachita orogenic belt locally (fig. 1) (also see Vanarsdale and Schweig, 1990). Along the southern basin margin, there are several 3- to 5-mi-wide swaths of rock adjacent to the Ouachita fault network that are buried at depths greater than 13,000 ft. These regions were not included in our SAU (see Brennan and others, 2010).

Analysis of a regional network of well logs suggests that the gross stratigraphic thickness of the Fayetteville-Caney interval, which encases the potential storage formations, increases from west to east across the SAU, and that the average thickness is about $250 \pm 50 \mathrm{ft}$. Analysis of the same set of well logs 
suggests that the average net-sandstone thickness (Batesville and Wedington) within this stratigraphic interval is relatively small at about $10-5 /+10 \mathrm{ft}$. Regional patterns in lithofacies for the reservoir units are poorly described, and we again caution that there is the potential for a Mississippian continental shelf margin to cross the southern half of the SAU, which would likely correspond to a transition to primarily fine-grained rocks in the southern part of the SAU.

There is little published information addressing the rock properties of the Batesville Sandstone or Wedington Sandstone Member in Arkoma Basin, so we relied on data from the analogous Morrowan sandstones that overlie the Mississippian strata. The overlying Lower Pennsylvanian (Morrowan Series; see Sutherland, 1988) sandstones were derived from a similar, northeasterly source area (Sutherland, 1988), and they experienced a similar burial history to the Mississippian sandstones (Arbenz, 1989). A compaction curve (reservoir-averaged porosity plotted against burial depth) constructed for Lower Pennsylvanian sandstones suggests basin-average porosity in the reservoir interval of $11 \pm 3$ percent (Nehring Associates, Inc., 2010). Permeability measurements from the same set of sandstones suggest that permeability for the reservoir interval ranges from 0.01 to $100 \mathrm{mD}$, and the most likely permeability for the units is about $10 \mathrm{mD}$.

Although there is little empirical evidence bearing on the quality of the formation waters in the Mississippian stratigraphic interval, a compilation of water-quality measurements (Breit, 2002) for both overlying and underlying stratigraphic intervals suggests that salinities approach, or exceed, 100,000 $\mathrm{mg} / \mathrm{L}$, even at shallow depths. Because the Mississippian strata deeper than 3,000 $\mathrm{ft}$ in Arkoma Basin appear to be too saline to be a source of potable water, Arkoma Basin may be a relatively favorable site for $\mathrm{CO}_{2}$ storage.

In order to place an upper limit on the enclosed pore volume within the SAU, we first attempted to bracket the area of stratigraphic and (or) structural closure. This is difficult to quantify in Arkoma Basin because there is very little historical oil and gas production from the Batesville and the Wedington. Given that the northern half of Arkoma Basin is neither highly faulted nor folded, we assumed that the greatest potential for enclosed pore space is within stratigraphic traps or combination structural-stratigraphic traps over open fault-related folds. We relied on information about the size of stratigraphic traps within Upper Mississippian deltaic strata from the nearby Black Warrior Basin of Mississippi and Alabama to infer the size of potential stratigraphic traps (Nehring Associates, Inc., 2010). The Upper Mississippian interval in Black Warrior Basin is not only highly productive with respect to oil and gas (and therefore well described), it shares a similar depositional setting and burial history to the equivalent section in Arkoma Basin (Cleaves and Bat, 1988; Nehring Associates, Inc., 2010) making it a potentially valid analog. In Black Warrior Basin, Upper Mississippian deltaic stratigraphic traps typically span about 3,000 acres of closure area, and given the density of fields producing within these types of traps in Black Warrior, we speculate that as many as 30 such enclosures could exist in the Batesville Sandstone and Wedington Sandstone Member SAU. In order to convert this closure area to a pore volume, we multiplied by a reservoir thickness and an upper limit on reservoir porosity. Typically, Chesterian deltaic stratigraphic traps in Black Warrior Basin involve a few tens of feet of net-porous reservoir (Nehring Associates, Inc., 2010). We derive an upper limit for reservoir porosity from the rock-property analysis described above. 


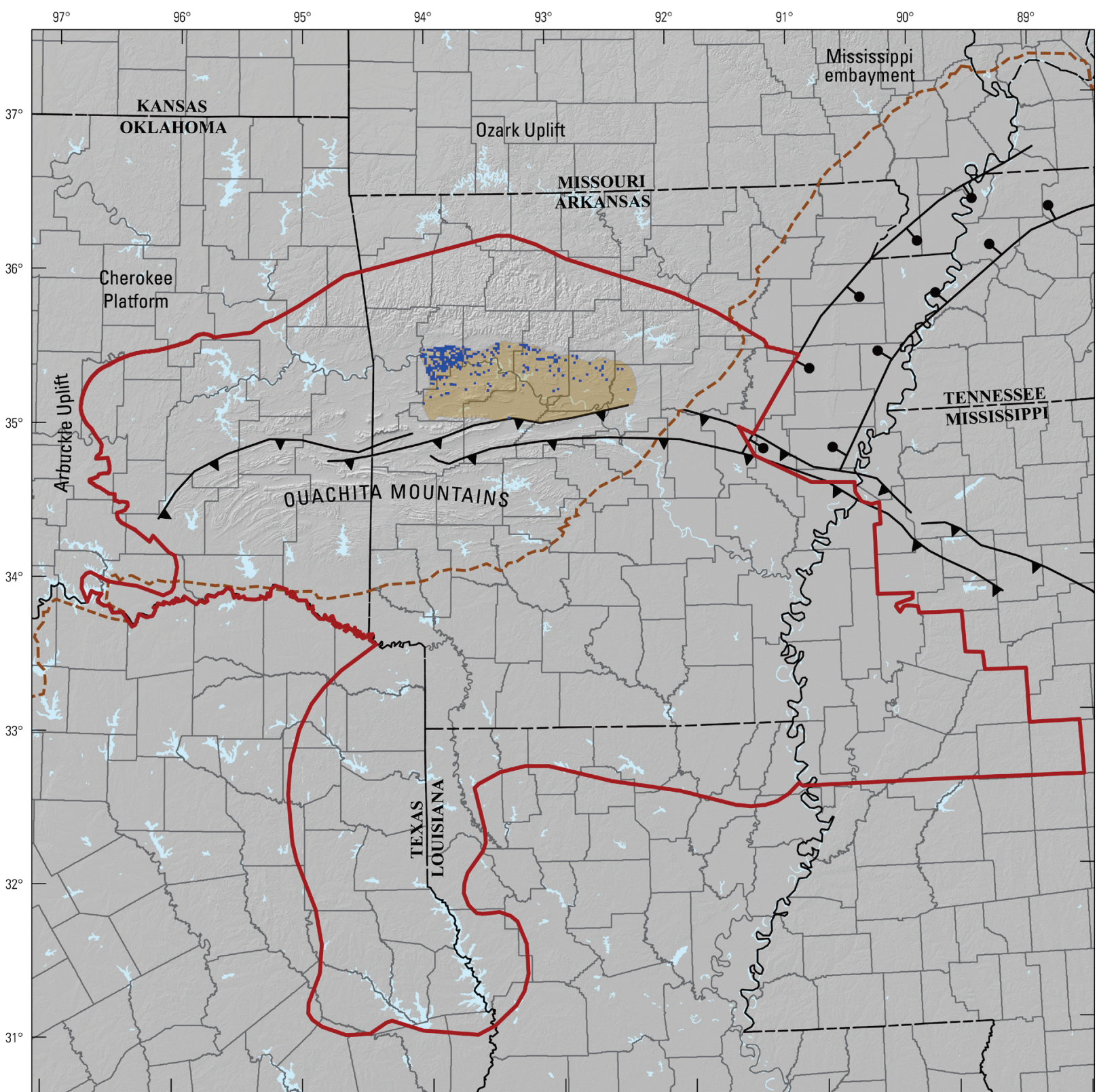

Elevation from U.S. Geological Survey National Elevation Dataset digital elevation model, 2009, 90-meter resolution

Albers Equal Area Projection Central meridian $95^{\circ} 00^{\prime} \mathrm{W}$
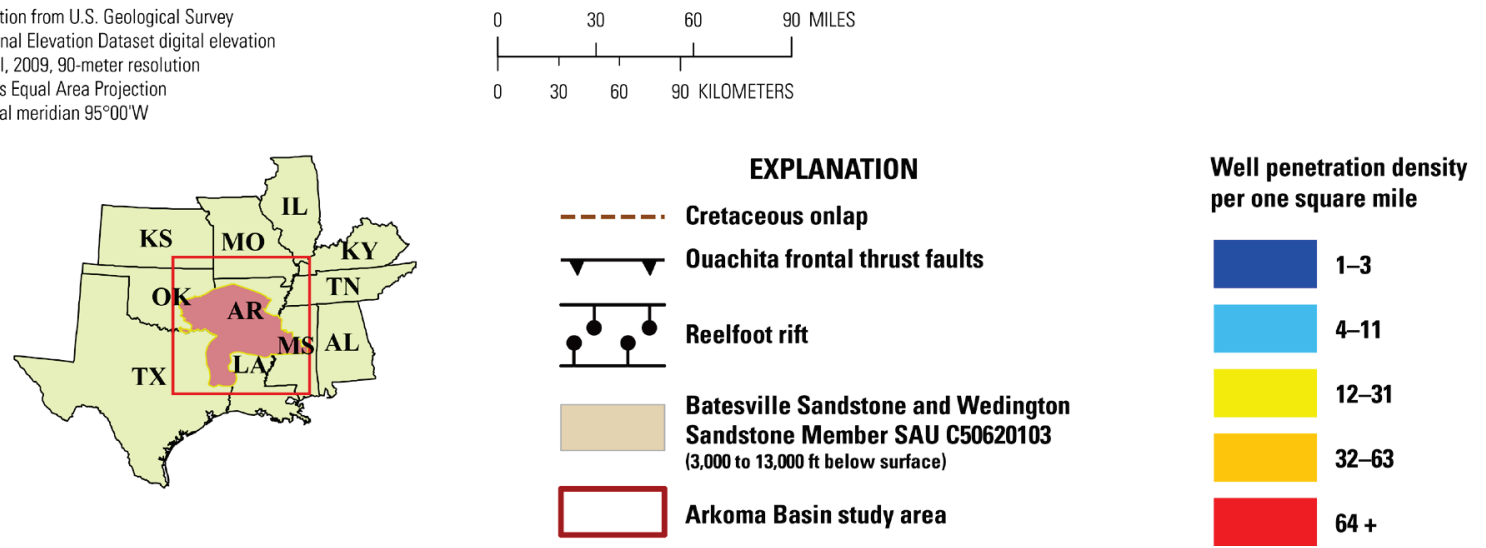

Figure 5. Map of the Batesville Sandstone and Wedington Sandstone Member Storage Assessment Unit (SAU) C50620103 boundary in the Arkoma Basin study area. Grid cells (one-square mile) display counts of wells derived from the IHS Energy Group (2011) well database that have penetrated the storage-formation top. Study area adapted from the Arkoma Basin Province Assessment Team (2010). 


\title{
Geologic Framework for the National Assessment of Carbon Dioxide Storage Resources-Kansas Basins
}

\author{
By Marc L. Buursink, Madalyn S. Blondes, Philip A. Freeman, Steven M. Cahan, and Christina A. DeVera
}

\section{Kansas Basins Introduction}

\section{Basin Physiography}

The Kansas Basins study area (fig. 6) for the national assessment of geologic $\mathrm{CO}_{2}$ storage encompasses the Salina and Sedgwick Basins, along with the Forest City Basin, Nemaha uplift, and Cherokee platform (Barrett, 1963; Busanus, 1987). The study area boundaries were delineated to the southwest of the Las Animas arch and along the Cambridge arch, Central Kansas uplift, Pratt anticline and southern Nemaha uplift (Barrett, 1963; Busanus, 1987; Higley, 1987). The Salina Basin (fig. 6) covers a large area (about 10,700 $\mathrm{mi}^{2}$ ) including an eastern portion of Nebraska and a north-central portion of Kansas (Coleman and Cahan, 2012). The basin is bounded to the west by the Cambridge arch and Central Kansas uplift, to the north by the Sioux arch, and to the east by the Nemaha uplift, whereas the southern boundary is a poorly defined structural saddle that separates it from the Sedgwick Basin (Evans, 1987; Prensky, 1995). The Salina Basin is characterized by Edmund and Goebel (1968) as a simple asymmetric syncline with a fairly uniform and gentle axial tilt from north to south; the basin deep is along the southwestern flank adjacent to the Central Kansas uplift. Though the basin contains units from the Precambrian basement to Quaternary alluvium, the Paleozoic rocks (Ordovician through Pennsylvanian) comprise the bulk of the stratigraphic section and the known hydrocarbon reservoirs (Powers, 1994). The Sedgwick Basin (fig. 6) is a broad south-plunging shallow embayment of the Anadarko Basin and covers an area of about 9,900 $\mathrm{mi}^{2}$ in south-central Kansas (Prensky, 1995; Coleman and Cahan, 2012). The basin is bounded to the west by the Central Kansas uplift, to the south by the Anadarko Basin, and to the east by the Nemaha anticline, whereas the northern boundary is poorly defined by the structural saddle dividing it from the Salina Basin (Prensky, 1995; Evans, 1987). The basin contains sedimentary rocks from the Cambrian through Tertiary, which are about 6,000 ft thick (Powers, 1994).

Besides the Salina and Sedgwick Basins, the Forest City Basin (fig. 6) extends from southwestern Iowa and northeastern Kansas to central Missouri (Charpentier, 1995a) with the Nemaha uplift at the southwest corner. The Forest City Basin is a shallow, intracratonic basin that contains Paleozoic sedimentary rocks (with a maximum thickness of 5,200 ft in southwestern Iowa) (Powers, 1994). The Nemaha uplift (fig. 6) is a regional paleostructural high that extends more than $500 \mathrm{mi}$ from southeastern Nebraska to south-central Oklahoma (Dolton and Finn, 1989; Powers, 1994; Charpentier, 1995b). The uplift is composed of multiple fault blocks and structural intersections; relief on the Precambrian basement surface locally exceeds $3,000 \mathrm{ft}$ and regionally diminishes to the south (Sims, 1985; Powers, 1994). The 1995 USGS oil and gas assessment estimates that the Nemaha Uplift Province is about 16,100 $\mathrm{mi}^{2}$ (Charpentier, 1995b). The Cherokee platform (fig. 6) extends from southeastern Kansas and part of southwestern Missouri to northeastern Oklahoma (Charpentier, 1995c). The platform is bounded to the east by the Ozark uplift, to the north by the Bourbon arch, to the west by the Nemaha uplift, and to the south by the Arkoma Basin. Although the Kansas Basins study area encompasses more physiography than 
just the Salina and Sedgwick Basins, these basins along with the Forest City Basin, Nemaha uplift, and Cherokee platform, were the focus areas for this assessment.

\section{Geologic History}

The Salina Basin was developed after the uplifting of the Nemaha anticline bisected the north Kansas Basins area and formed the Salina Basin on the west and the Forest City Basin on the east (Lee and others, 1948). Initially these basins were structural, but during the Pennsylvanian, they subsided and accumulated Pennsylvanian sediment (Lee and others, 1948). Three principal periods of folding are identified in the Salina Basin by thickness maps, and two secondary periods of folding are indicated by structural maps (Lee, 1956). The first folding episode occurred between Neoproterozoic and Middle Ordovician time, the second folding episode occurred between Middle Ordovician and Early Mississippian, and the third folding episode occurred after Early Mississippian and was of maximum intensity during Late Mississippian and Early Pennsylvanian (Lee, 1956). There is faulting along the southwestern and southern flanks of the Salina Basin, but there is very little to no faulting within the basin (Edmund and Goebel, 1968).

The Sedgwick Basin is a major post-Mississippian and pre-Desmoinesian structural feature (Merriam, 1963). The basin, which is relatively shallow and southerly plunging, may be considered an extension of the Anadarko Basin, and the rocks in the basin are characterized by facies change and by increased thickness southward from the shallower shelf area into the deeper part of the Anadarko Basin proper (Merriam, 1963). Furthermore, according to Puyear and Mazzullo (2009), the Sedgwick Basin was an embayment of the epicontinental Permian sea (Blakey, 2011), and tectonic compression occurred in the basin during Mississippian time when large-scale anticlines were formed. For additional details on the Salina and Sedgwick Basins, along with the Forest City Basin, Nemaha uplift, and Cherokee platform and also for the geologic history for surrounding areas, please refer to Merriam (1963), Anderson and Wells (1968), Adkison (1972), and Newell and others (1987).

\section{Hydrocarbon Exploration and Production}

Most of the Salina Basin is nonproductive for hydrocarbons because of the lack of sufficiently rich and mature source rocks (Prensky, 1995; Newell and Hatch, 2000). Potential hydrocarbon source rock maturity decreases in a northwest direction from the Forest City Basin (Prensky, 1995). Large areas of the Salina Basin remain untested, though about 600 wildcat wells have been drilled, and there have been no commercial discoveries in more than 60 years of exploration up to 1995 despite numerous oil shows (Prensky, 1995). In the Sedgwick Basin, the southward plunge of the productive horizons results in their increasing depth toward the Anadarko Basin (Prensky, 1995). In the Forest City Basin hydrocarbon province, exploration began in 1860 with drilling in Miami County, Kansas, resulting in the discovery of oil near Paola; the first discovery larger than 1 million barrels of oil equivalent (MMBOE) occurred in 1882, also in Miami County, Kansas (Paola-Rantoul field) (Charpentier, 1995a). Up to 1995, more than 10,000 wells have been drilled, and 21 fields larger than $1 \mathrm{MMBOE}$ have been discovered. Discovered resources as of the end of 1990 in the province total more than $100 \mathrm{MMBO}$ and more than $15 \mathrm{BCFG}$ (Charpentier, 1995a). In the Nemaha uplift hydrocarbon province, exploration began before the turn of the century with gas discovered in 1902, and the first discovery larger than 1 MMBOE occurred in 1903 in Cowley County, Kansas (Dexter field) (Charpentier, 1995b). Up to 1995, more than 45,000 wells have been drilled, and 194 fields larger than 1 MMBOE have been discovered, and up to 1990, discovered resources have been more than 2.4 billion barrels of oil (BBO) and more than 6.1 trillion cubic feet of gas (TCFG) (Charpentier, 1995b). In the Cherokee platform hydrocarbon province, exploration began in the 1860s, and the first discovery took place in 1873 in Allen County, Kansas (Iola field) (Charpentier, 1995c). Up to 1995, more than 200,000 wells have been drilled, and 431 fields larger than $1 \mathrm{MMBOE}$ have been discovered, and discovered resources as of 1990 in the province were more than $5.3 \mathrm{BBO}$ and 
4.3 TCFG (Charpentier, 1995c). "This part of the Mid-Continent region is one of the oldest oil and gas producing areas of the United States" (Powers, 1994).

\section{Storage Resource Assessment}

The regional $\mathrm{CO}_{2}$ storage resource assessment of the Kansas Basins resulted in two SAUs located in the Salina and Sedgwick Basins only. Each SAU is described in the following sections, and each includes a regional seal and storage formation(s) pair. The SAU name is typically based on the whole stratigraphic interval or lithology considered for storage (fig. 7). The geographic extents of the SAUs are defined by the storage-formation-top depth and by the geologic characteristics of the reservoir and the overlying caprock. The geologic characteristics described or considered for each SAU include both the seal and reservoir thickness distribution and reservoir quality (such as net-to-gross ratio, porosity, and permeability). Furthermore, we identify regional trends in groundwater quality because the U.S. Environmental Protection Agency $(2009,2010)$ stipulates that aquifers with a TDS concentration less than $10,000 \mathrm{mg} / \mathrm{L}$ may not be used for $\mathrm{CO}_{2}$ storage. For the Kansas Basins assessment, groundwater quality, based on TDS content, was assembled from multiple sources as described in subsequent sections.

The assessment is conducted following the methodology of Burruss and others (2009), Brennan and others (2010), and Blondes and others (2013), which prescribe the appropriate geologic model detailed above, a probabilistic statistical analysis, and subsurface conditions favoring supercritical phase $\mathrm{CO}_{2}$. Subsurface conditions favoring $\mathrm{CO}_{2}$ storage at high density include relatively high basin pressures and temperatures (Buursink, 2012). Based on the methodologies, we differentiate our assessed storage resource between residual trapping (typically larger, but less certain) and buoyant trapping (typically smaller, but more certain). Residual trapping occurs at the pore scale, and buoyant trapping is analogous to stratigraphic and (or) structural hydrocarbon trapping. The minimum buoyant-trapping volume is determined from cumulative hydrocarbon production with the known hydrocarbon reserve volume, whereas the most likely buoyant-trapping volume adds the minimum volume and the estimated volume of undiscovered resources (Gautier and others, 1995; Brennan and others, 2010). The maximum buoyant resource is determined by the assessment geologist. Upon completion of the assessment, the following SAUs, listed by name and number in parentheses, are described: Lower Paleozoic Composite SAU (C50560101) and Hunton Group SAU (C50560102) (fig. 7). 


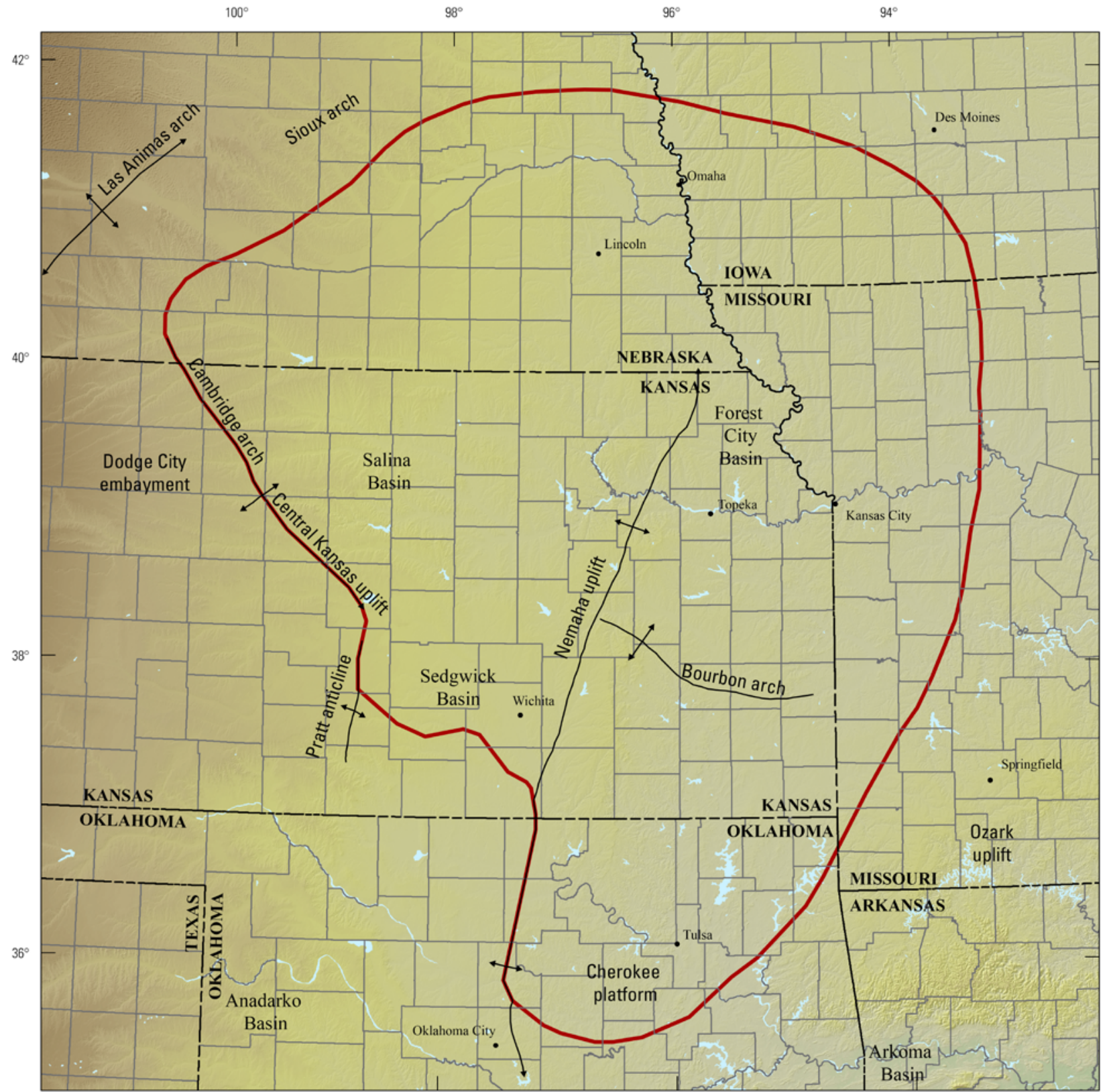

Elevation from U.S. Geological Survey National Elevation Dataset digital elevation model, 2009, 90-meter resolution

Albers Equal Area Projection

Central meridian $96^{\circ} 30^{\circ} \mathrm{W}$
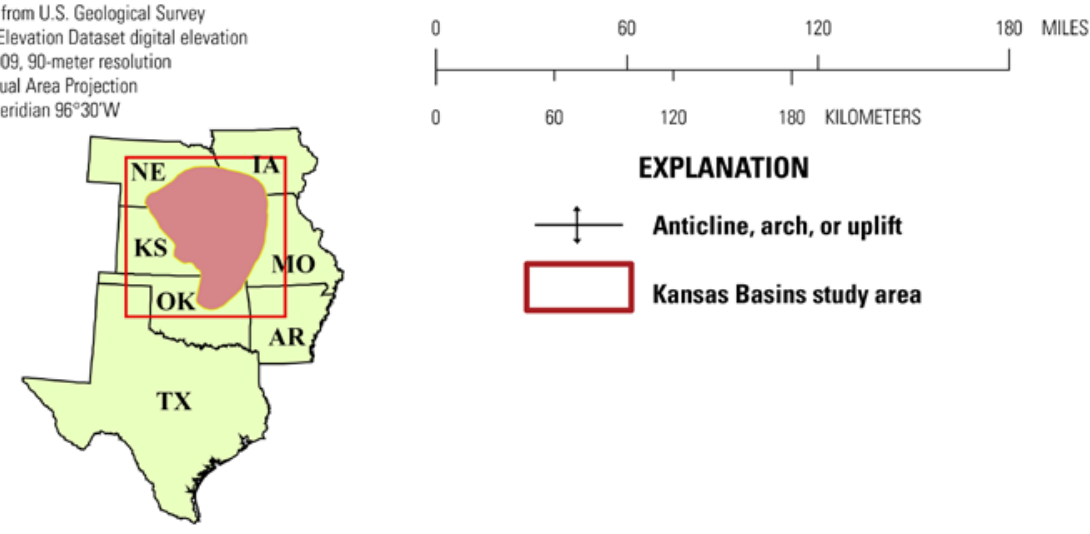

$\begin{array}{lllll}0 & 60 & 120 & 180 & \text { KILOMETERS }\end{array}$

EXPLANATION

Figure 6. Map of the Kansas Basins study area including major tectonic elements (after Busanus, 1987; Barrett, 1963) and boundaries adapted from the U.S. Geological Survey national oil and gas assessment (NOGA) (Prensky, 1995; Charpentier, 1995a,b,c). 


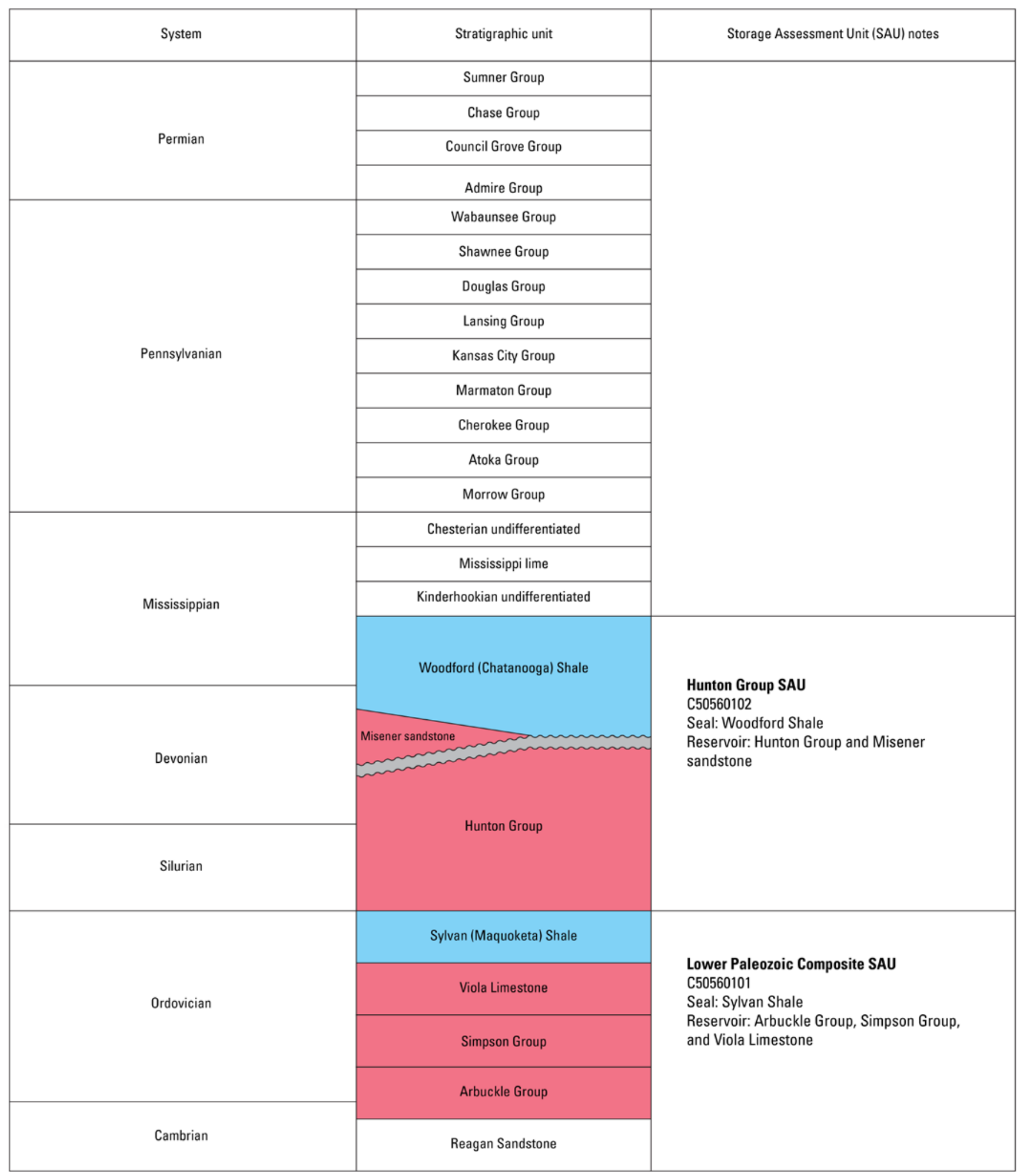

Figure 7. Generalized stratigraphic column of geologic units in Kansas Basins study area (adapted from Prensky, 1995). Storage assessment units (SAUs) consist of a reservoir (red) and a regional seal (blue). Wavy lines indicate unconformable contacts, and gray sections represent unconformities or hiatuses. In some cases, subdivisions of units or lesser known correlative units are not shown. 


\title{
Lower Paleozoic Composite SAU C50560101
}

\author{
By Marc L. Buursink
}

The Lower Paleozoic Composite SAU consists of those portions of the preserved siliciclastic and carbonate lithology deemed suitable as reservoirs for $\mathrm{CO}_{2}$ storage occurring beneath a regionally extensive seal in the Kansas Basins (fig. 8). The Arbuckle Group, Simpson Group, and Viola Limestone make up this composite SAU (fig. 7). The Upper Cambrian and Lower Ordovician Arbuckle Group includes thick, almost pure carbonate successions, which are often dolomitized from subaerial and subsurface diagenesis and are enhanced by fracturing (Prensky, 1995; Johnson and Merriam, 2001; Franseen and others, 2004). A very large carbonate platform with cyclical sea-level variation was the depositional setting for the Arbuckle Group (Johnson and Merriam, 2001). The Middle Ordovician Simpson Group comprises sandstone, interbedded shale, and carbonate beds occurring above Arbuckle rocks and beneath Viola Limestone, which are separated by minor unconformities (Taff, 1902; Lee and others, 1946; Cole, 1975). The Simpson Group sandstones are exceptional in this carbonate and shale dominated section because their composition and deposition were complicated through changes in subsidence, quartz sand supply, and tectonics (Prensky, 1995; Johnson, 1997). The Upper Ordovician Viola Limestone is a massive white and bluish limestone with concretions in the lower and middle sections (Taff, 1902). Self-sourced hydrocarbons are produced from both fracture porosity and primary porosity zones in the Viola Limestone (Prensky, 1995; Evans, 1984). The Sylvan Shale overlies the Viola Limestone and functions as the regionally thick sealing formation (Adler and others, 1971; Adkison, 1972; IHS Energy Group, 2010) for the purpose of this assessment. The Upper Ordovician Sylvan Shale is equivalent to the Maquoketa and Cason Shales, and these were all deposited in relatively deep and calm waters (Johnson, 1997; Blakey, 2011). Regionally the Sylvan Shale is a soft, green, fissile shale that forms swales between the harder under- and overlying limestone formations (Taff, 1902; Adler and others, 1971).

The composite SAU boundaries are defined by the depth below the surface of the uppermost storage formation. Here formation picks for the Viola Limestone, reported in a commercial database (IHS Energy Group, 2010), help define the top of the storage interval. The Lower Paleozoic Composite SAU C50560101 occurs between 3,000 and 4,000 ft in depth and has a most likely area of about 2,415,000 acres (fig. 8). These interpretations are supported by the cross sections and isopach maps from Adler and others (1971) and Rascoe and Hyne (1987) and by descriptions and maps from Cole (1975). Analyses of the stratigraphy, net-to-gross ratio, and net-porous intervals for the three formations within the composite SAU were obtained mainly from Mairs (1966) and Ramondetta (1990) for the Viola Limestone, from Holden (1965) and Statler (1965) for the Simpson Group, and from Latham (1968) and Ching and Friedman (2000) for the Arbuckle Group. The Lower Paleozoic Composite SAU gross thickness ranges from 200 to $800 \mathrm{ft}$ with a net thickness between about 70 and $250 \mathrm{ft}$. Ultimately, the SAU was limited to the Salina and Sedgwick Basins because the minimum assessment seal-thickness and depth requirements are met only in this part of the study area.

The lower Paleozoic rocks are a somewhat productive hydrocarbon interval in the Kansas Basins and reservoir-quality data is reported in multiple forms. Besides published porosity values (Walters, 1958; Ramondetta, 1990; Ching and Friedman, 2000) and permeability values (Read and Richmond, 1993; Carr and others, 2005), additional average field values were obtained from Nehring Associates, Inc. (2010), a commercial oil and gas database. The Lower Paleozoic Composite SAU porosity ranges from 5 to 15 percent, and permeability ranges between 0.01 and $1,000 \mathrm{mD}$. 
In addition to the storage-formation thicknesses and reservoir quality, the groundwater quality and buoyant storage were also assessed. Water-quality data obtained for the SAU area from multiple

published databases and tables (Jorgensen and others, 1993; Breit, 2002; Carr and others, 2005) indicated mostly saline groundwaters. Therefore, a large area fraction of the SAU has a groundwater TDS value greater than the USDW limit of $10,000 \mathrm{mg} / \mathrm{L}$. To create a probabilistic maximum volume for buoyant trapping for each SAU, both the size and location of hydrocarbon plays (Prensky, 1995), field size information from the Kansas Geological Survey (2012), along with the Nehring Associates, Inc. (2010) average field size and location, were used. 


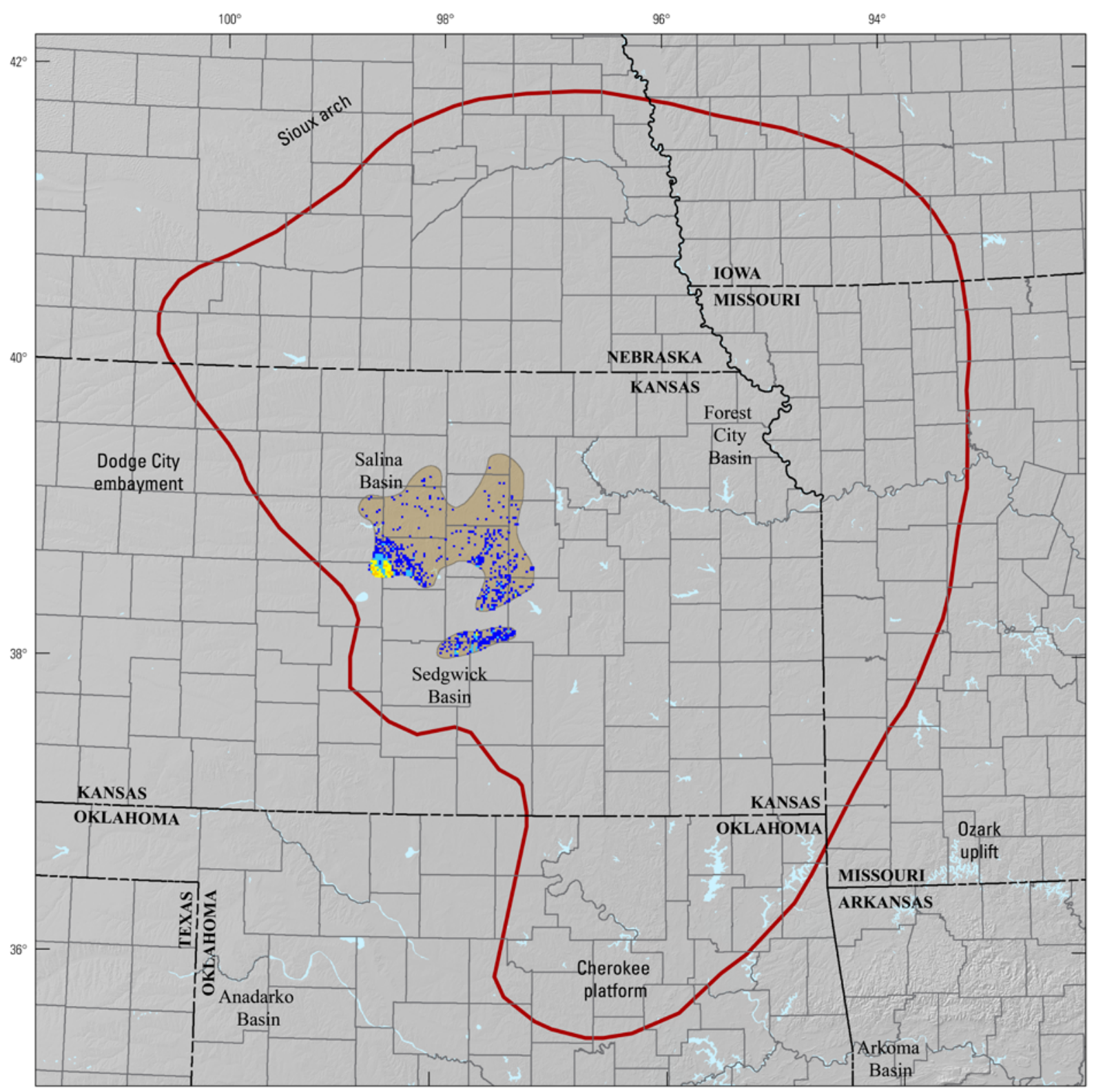

Elevation from U.S. Geological Survey National Elevation Dataset digital elevation model, 2009, 90-meter resolution Albers Equal Area Projection
Central meridian $96^{\circ} 30^{\circ} \mathrm{W}$

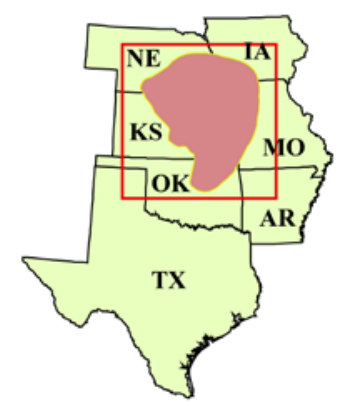

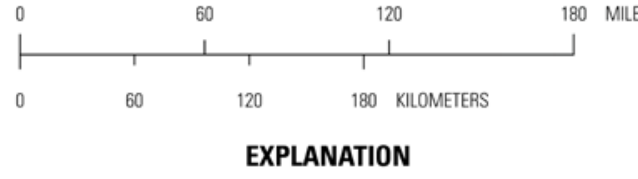

Lower Paleozoic Composite SAU C50560101 $(3,000$ to $13,000 \mathrm{ft}$ below surface)

Kansas Basins study area

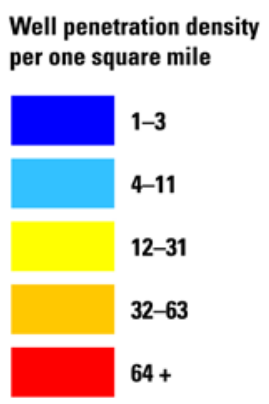

Figure 8. Map of the Lower Paleozoic Composite Storage Assessment Unit (SAU) C50560101 in the Kansas Basins study area. Grid cells (one-square mile) display counts of wells derived from the IHS Energy Group (2011) well database that have penetrated the storage-formation top. Study area adapted from the U.S. Geological Survey national oil and gas assessment (NOGA) (Prensky, 1995; Charpentier, 1995a,b,c). 


\title{
Hunton Group SAU C50560102
}

\author{
By Marc L. Buursink
}

The Hunton Group SAU consists of those portions of the preserved siliciclastic and carbonate lithology deemed suitable as reservoirs for $\mathrm{CO}_{2}$ storage occurring beneath a regionally extensive seal in the Kansas Basins (fig. 9). Included in this assessment are the informal Misener sandstone and Hunton Group intervals (fig. 7). The Misener sandstone comprises quartz grains in a carbonate cement and tends to produce in abundant quantity but is elusive to oil discovery (Francis, 1991). These Devonian rocks of the Misener were deposited during minor changes in sea level, and the reservoir distribution consists of lenses within incised-valley fills (Busanus, 1987; Kuykendall and Fritz, 2001). For the purpose of this SAU, these widely scattered rocks are not included in the SAU name. The Misener sandstone unconformable overlies the Hunton Group (Amsden and Klapper, 1972). The Hunton Group, first identified as a limestone by Taff (1902), now includes limestone and dolomite strata of Silurian and Early Devonian ages (Zeller, 1968). The Hunton Group consists of, in descending order, the Bois d'Arc Limestone, the Haragan Shale, Henryhouse Formation (dolomite and calcareous shale), and the Chimneyhill Limestone (limestone with dolomite and calcareous shale) (Amsden, 1980; Fritz and Medlock, 1995). The carbonate rocks were deposited on a shallow ramp where sea-level changes caused migration of facies and generated multiple disconformities, which are now used to define the stratigraphic divisions above (Johnson and Merriam, 2001; Blakey, 2011). The Chattanooga (Woodford equivalent) Shale overlies the Hunton Group and functions as the regionally thick sealing formation (Conant and Swanson, 1961; Amsden and others, 1967; Isom, 1976) for the purpose of this assessment. This shale is dark gray to black throughout its areal extent; the lower part is commonly siliceous with phosphate nodules and lenses and locally contains thin beds of chert and is generally considered to be a good source rock (Kuykendall and Fritz, 2001). The Chattanooga Shale is Late Devonian and Early Mississippian in age, is equivalent to the Kinderhook Shale and the Woodford Shale of Oklahoma, and is typically picked at the top of a strong positive gamma-ray response in well logs in Oklahoma (Swanson, 1961; Hester and others, 1990; IHS Energy Group, 2011). The Chattanooga Shale was deposited in a low-energy marine environment, though relatively deep sea or restricted basin deposition are possible (Conant and Swanson, 1961; Ettensohn, 1995; Blakey, 2011).

The SAU boundaries are defined by the depth below the surface of both the Hunton Group and the Misener sandstone. Here rock-unit picks, reported in a commercial database (IHS Energy Group, 2010), for the two units help define the top of the storage interval. The Hunton Group SAU occurs between 3,000 and 3,700 ft in depth and has about a 1,027,000-acre most likely area (fig. 9). These interpretations are supported by the cross sections and isopach maps from Merriam (1963), Adler and others (1971), and Rascoe and Hyne (1987). Analyses of the stratigraphy, net-to-gross ratio, and net-porous intervals for the two units within the SAU were obtained through published logs and cross sections (Francis, 1991; Fritz and Medlock, 1995; Kuykendall and Fritz, 2001). The Hunton Group SAU gross thickness ranges from 55 to $210 \mathrm{ft}$ with a net thickness between 20 and $90 \mathrm{ft}$. Ultimately, the SAU was limited to the Salina and Sedgwick Basins because the minimum assessment seal-thickness and depth requirements are met only in this part of the study area.

The Hunton Group rocks are a somewhat productive hydrocarbon interval in the Kansas Basins, and reservoir-quality data is reported in multiple forms. Besides published porosity values (Francis, 1991; Busanus, 1987) and permeability values (Newell and others, 2001; Northcutt, 1993), additional average field values were obtained from Nehring Associates, Inc. (2010), a commercial oil and gas database. The 
Hunton Group SAU porosity ranges from 6 to 10 percent, and the permeability ranges from 0.01 to 120 $\mathrm{mD}$.

In addition to the storage-formation thicknesses and reservoir quality, the groundwater quality and buoyant storage were also assessed. Water-quality data obtained for the SAU area from a published database (Breit, 2002) indicated saline groundwaters. Furthermore, evaporite beds in the Kansas Basins yield brackish groundwaters (Merriam, 1963; Lane and Miller, 1965). Therefore, the entire area fraction of the SAU has a groundwater TDS value greater than the USDW limit of 10,000 mg/L. To create a probabilistic maximum volume for buoyant trapping for each SAU, both the size and location of hydrocarbon plays (Prensky, 1995), field size information from the Kansas Geological Survey (2012) and from Newell and others (1987), and the Nehring Associates, Inc. (2010) average field size and location were used. 


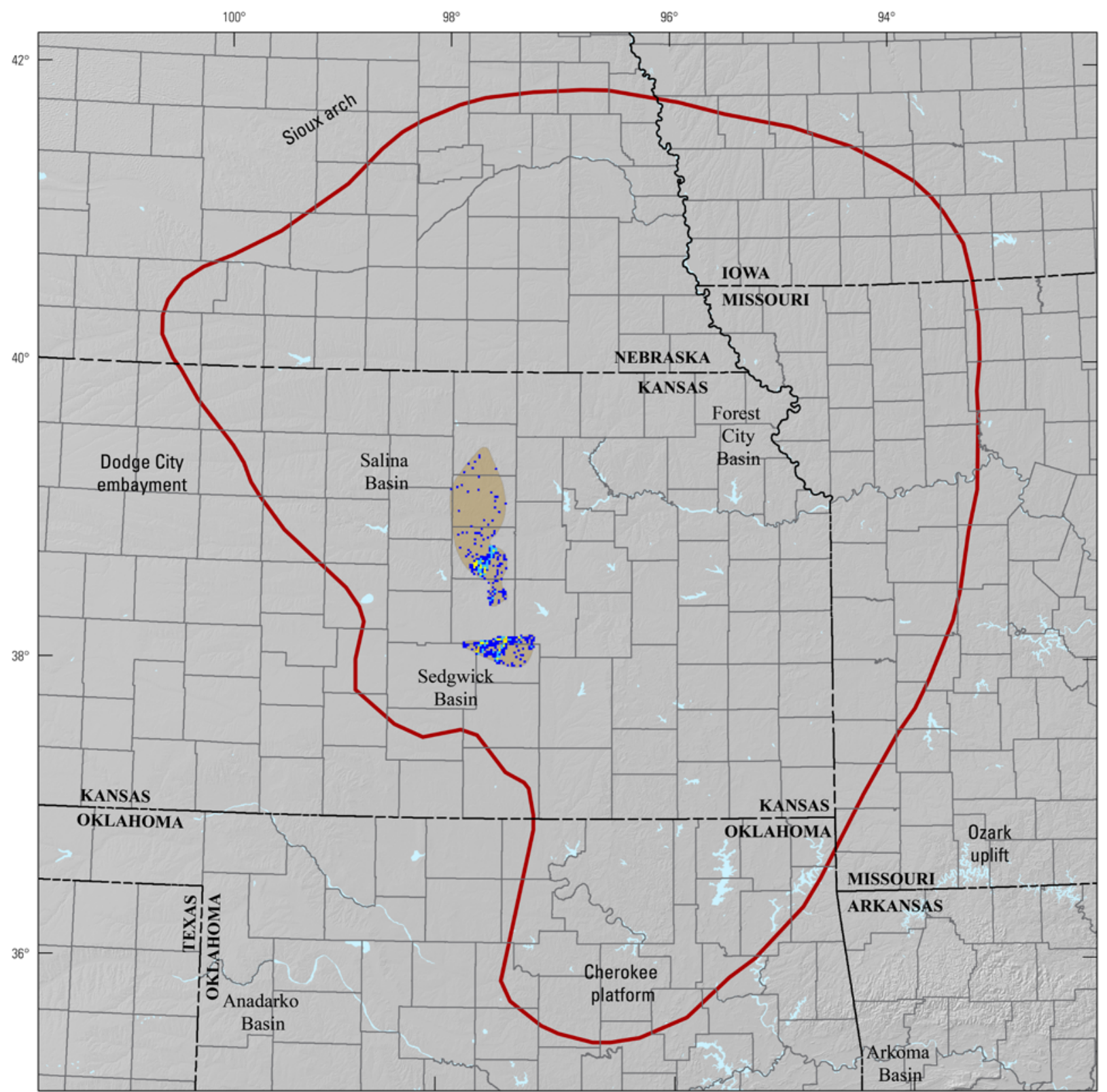

Elevation from U.S. Geological Survey National Elevation Dataset digital elevation model, 2009, 90-meter resolution

Albers Equal Area Projection

Central meridian $96^{\circ} 30^{\circ} \mathrm{W}$

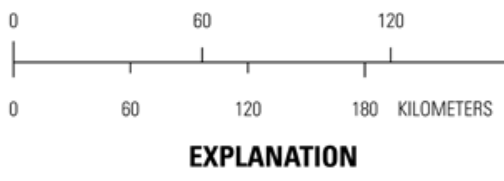

180 MILES

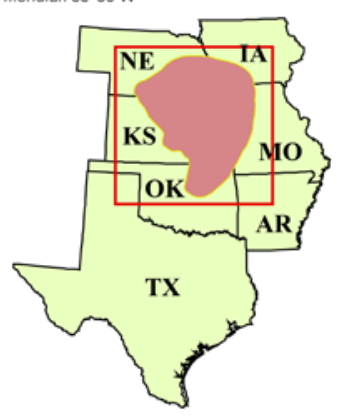

促ON

Well penetration density per one square mile

Hunton Group SAU C50560102

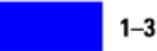

3,000 to $13,000 \mathrm{ft}$ below surface)

1-3

Kansas Basins study area

4-11

$12-31$

$32-63$

$64+$

Figure 9. Map of the Hunton Group Storage Assessment Unit (SAU) C50560102 in the Kansas Basins study area. Grid cells (one-square mile) display counts of wells derived from the IHS Energy Group (2011) well database that have penetrated the storage-formation top. Study area adapted from the U.S. Geological Survey national oil and gas assessment (NOGA) (Prensky, 1995; Charpentier, 1995a,b,c). 


\title{
Geologic Framework for the National Assessment of Carbon Dioxide Storage Resources-Midcontinent Rift Basin
}

\author{
By Marc L. Buursink, Steven M. Cahan, and Celeste D. Lohr
}

\section{Midcontinent Rift Basin Introduction}

\section{Basin Physiography}

The Midcontinent Rift Basin (MCRB) is a large arcuate Mesoproterozoic rift zone that extends from southeastern Ontario, Canada, to northern Michigan and terminates in northeast Kansas and has an area of about 100,515 $\mathrm{mi}^{2}$ (Coleman and Cahan, 2012) (fig. 10). The boundary for this study area is derived from the basin outlines shown in Ojakangas and others (2001) and in Van Schmus and Hinze (1985). For most of its extent, the MCRB does not have a surface expression as a rift basin, and thus its boundaries and structure has been determined by gravity and aeromagnetic maps (Chandler and others, 1989), seismic profiles, and infrequent well penetrations; however, it is exposed in western Michigan, northern Wisconsin, and southeastern Minnesota (Coleman and Cahan, 2012). The MCRB is characterized by broad medial horsts, mainly comprising layered basaltic volcanic rock, bounded by highangle normal or reverse faults, and flanked by asymmetric half-graben-style basins mostly filled with sedimentary clastic rock, which may be as much as 30,000 ft thick (Palacas, 1995). The depths calculated for these basins depend on the densities assumed for the sedimentary rocks interpreted from geophysical surveys (McSwiggen and others, 1987).

\section{Geologic History}

The main MCRB section is a failed continental rift of Mesoproterozoic age (about 1.1 billion years ago); a related arm of the rift extends from eastern Lake Superior southeastward to the southern boundary of Michigan (Palacas, 1995). A new ocean basin nearly formed before rifting ceased, likely because of the distant Grenville continental collision to the east. Broad sagging and subsidence, combined with a system of axial half-grabens, provided accommodation space along the length of the MCRB (Ojakangas and others, 2001). Four interpreted geophysical surveys show the basin asymmetry and the off-axis placement of mafic rocks, along with the positions of the interpreted growth faults (Chandler and others, 1989). For example, seismic-reflection surveys by the Great Lakes International Multidisciplinary Program on Crustal Evolution (GLIMPCE) (Behrendt and others, 1988) in 1986 imaged the deep structure of the rift beneath the Great Lakes and revealed an asymmetrical graben whose existence and magnitude was previously unknown (Cannon and others, 1989). Early sedimentation in the MCRB was followed by further broad crustal sagging and deposition of progressively more mature red-bed, fluvial sediments with a distant source (Ojakangas and others, 2001).

Specifically, only Keweenawan age rocks are exposed in the Lake Superior region and can be roughly divided into two groups: rift-basin igneous rocks (Duluth Complex of the Keweenawan Supergroup) and the overlying upper Keweenawan Supergroup sedimentary rocks (Dickas, 1986; Van Schmus and Hinze, 1985). These clastic rocks comprise an older Oronto Group and a younger Bayfield Group. The Nonesuch Formation is the primary formation of the Oronto Group and is composed of porous fluvial, deltaic, and shoreline sandstones (Thorleifson, 2008). The underlying Copper Harbor Conglomerate also has acceptable porosity (Thorleifson, 2008). Ultimately, geophysical surveys provide 
the key results on sedimentary rock depth and distribution (Thorleifson, 2008; Chandler and others, 1989).

\section{Hydrocarbon Exploration and Production}

No commercial hydrocarbons have been found in the MCRB. Nevertheless, NOGA identified one hypothetical conventional play (Precambrian Midcontinent Rift System Play) in their Superior Province oil and gas system (Palacas, 1995). Basin modeling and source rock studies have indicated the possibility of hydrocarbons in this province (Thorleifson, 2008; Palacas, 1995). For example, in the Nonesuch Formation, live oil seeps in the White Pine Copper Mine in Michigan confirm that liquid hydrocarbons have been generated (Thorleifson, 2008). Limited wildcat drilling has been documented in the MCRB. For example, in 1987, Amoco Production Company drilled the Eischeid No. 1 petroleum exploration well in west-central Carroll County, Iowa, to a total depth of 17,851 ft (Thorleifson, 2008). The well had minor occurrences of gaseous hydrocarbons detected in the Proterozoic section (Thorleifson, 2008). In 1992, the Terra-Patrick No. 7-22 deep hydrocarbon test was completed in Bayfield County, Wisconsin, to a depth of $4,966 \mathrm{ft}$ and had very minor occurrences of natural gas detected within carbonaceous shale of the Nonesuch Formation (Thorleifson, 2008). This well marked the end of about nine years of hydrocarbon exploration in Mesoproterozoic rocks of the midcontinent rift trend of Wisconsin and may likely be the last well drilled in the trend until geologic interpretations and regulatory procedures improve (Thorleifson, 2008).

\section{Storage Resource Assessment}

The regional $\mathrm{CO}_{2}$ storage resource investigation of the MCRB resulted in no SAUs. The investigation was conducted following the methodology of Blondes and others (2013), Brennan and others (2010), and Burruss and others (2009), which prescribe the appropriate geologic model, a probabilistic statistical analysis, and subsurface conditions favoring supercritical phase $\mathrm{CO}_{2}$. Thorleifson (2008) concluded that the limited available information (on MCRB sediment lithostratigraphy, depositional history, physical properties, and hydrogeology) indicates that the MCRB has attributes that make it far less suitable for storage than other sites currently being considered across the country. Furthermore, permeability loss of the Copper Harbor Conglomerate at high pressure makes it an unlikely candidate for storage (Hart and LaMaskin, 2011). Ultimately, because suitable storage formations meeting our size, depth, reservoir-quality, and regional-seal guidelines were not found, SAUs were not generated for the MCRB study area. 


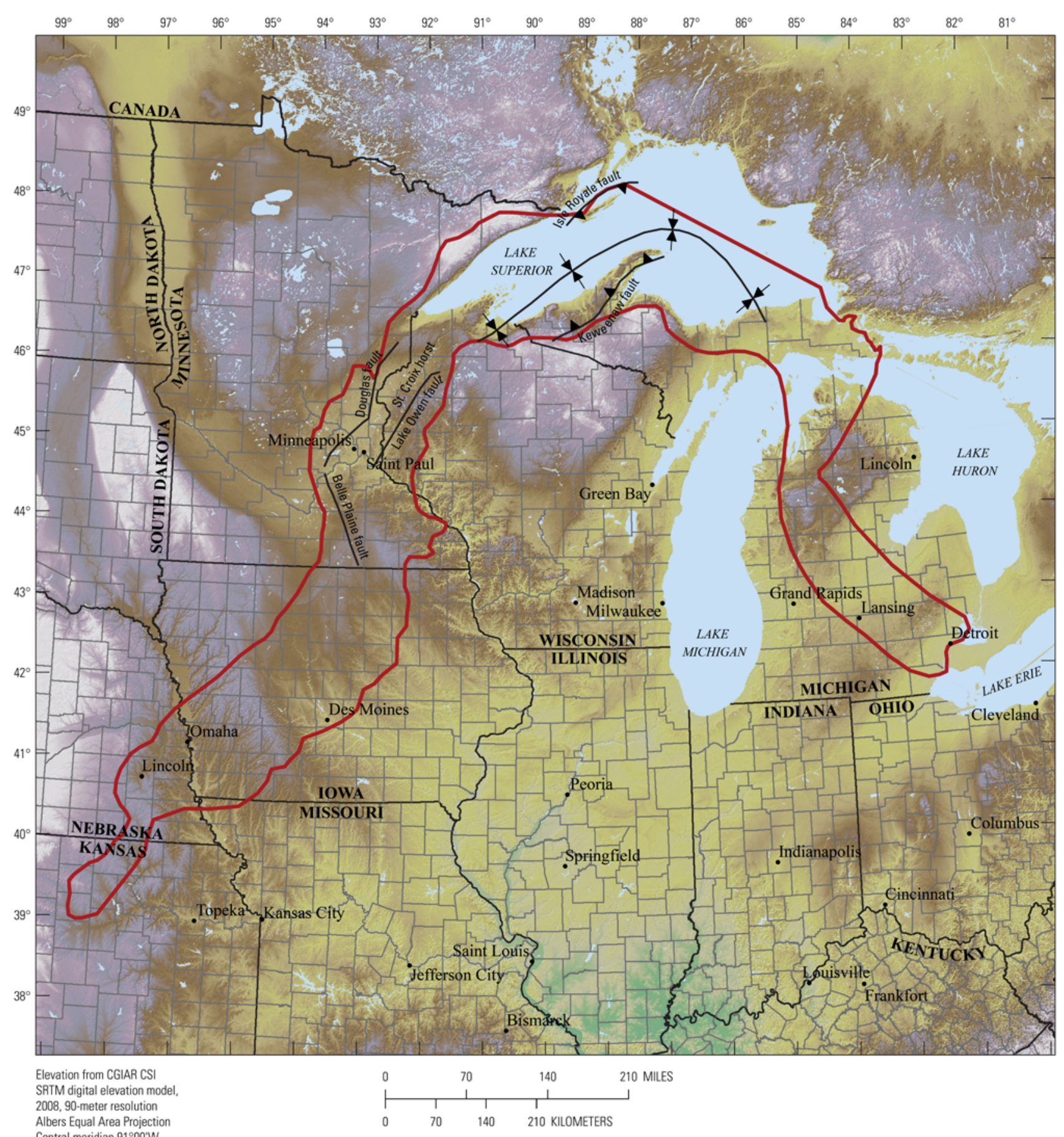

Central meridian $91^{\circ} 00^{\prime} W$

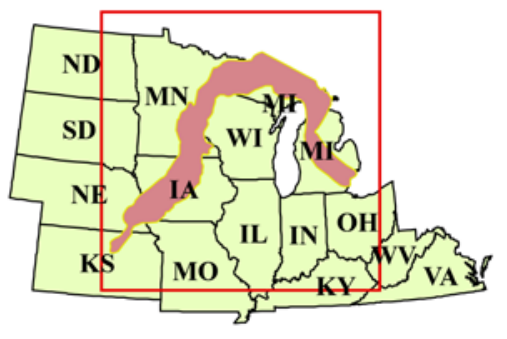

EXPLANATION

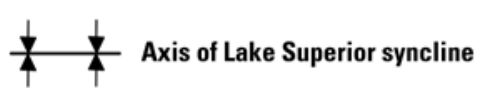

Midcontinent Rift Basin study area

Figure 10. Map of the Midcontinent Rift Basin study area including major tectonic elements (after Thorleifson, 2008; Huber, 1975) and boundaries adapted from the U.S. Geological Survey national oil and gas assessment (NOGA) (Gautier and others, 1995). 


\section{Acknowledgments}

Paul Schuben and Brian Varela helped to compile the drilling and hydrocarbon production data for the study areas. Troy Cook, Mahendra Verma, and Hossein Jahediesfanjani helped to interpret the petroleum engineering data for the study areas. The Oklahoma Geological Survey, the Southwest Regional Partnership on Carbon Sequestration, David Hart from the Wisconsin Geological and Natural History Survey, and Harvey Thorleifson and Val Chandler from the Minnesota Geological Survey helped by supplying geologic information and interpretations for the study areas. The content and presentation of this report benefited greatly from the technical reviews by James Coleman and Philip Nelson.

\section{References Cited}

Adkison, W.L., 1972, Stratigraphy and structure of the Middle and Upper Ordovician rocks in the Sedgwick Basin and adjacent areas, south-central Kansas: U.S. Geological Survey Professional Paper 702, 33 p., 5 pl., scale 1:500,000.

Adler, F.J., Caplan, W.M., Carlson, M.P., Goebel, E.D., Henslee, H.T., Hicks, I.C., Larson, T.G., McCracken, M.H., Parker, M.C., Rascoe, Bailey, Jr., Schramm, M.W., Jr., and Wells, J.S., 1971, Future petroleum provinces of the mid-continent, region 7, in Cram, I.H., ed., Future petroleum provinces of the United States - Their geology and potential: American Association of Petroleum Geologists Memoir 15, v. 2, p. 985-1120.

Amsden, T.W., 1949, Stratigraphy and paleontology of the Brownsport Formation (Silurian) of western Tennessee: New Haven, Conn., Yale University Press, Peabody Museum of Natural History Bulletin 5, $138 \mathrm{p}$.

Amsden, T.W., 1951, Brachiopods of the Henryhouse Formation (Silurian) of Oklahoma: Journal of Paleontology, v. 25, no. 1, p. 69-96.

Amsden, T.W., 1958a, Stratigraphy and paleontology of the Hunton Group in the Arbuckle Mountain region, Pt. II, Haragan articulate brachiopods: Oklahoma Geological Survey Bulletin, v. 78, p. 9-142.

Amsden, T.W., 1958b, Stratigraphy and paleontology of the Hunton Group in the Arbuckle Mountain region, Pt. V, Bois d'Arc articulate brachiopods: Oklahoma Geological Survey Bulletin, v. 82, 110 p.

Amsden, T.W., 1980, Hunton Group (Late Ordovician, Silurian, and Early Devonian) in the Arkoma Basin of Oklahoma: Oklahoma Geological Survey Bulletin 129, 136 p.

Amsden, T.W., Caplan, W.M., Hilpman, P.L., McGlasson, E.H., Rowland, T.L., and Wise, O.A., Jr., 1967, Devonian of the southern midcontinent area, United States, in Oswald, D.H., ed., International symposium on the Devonian System, vol. 1: Calgary, Alberta, Canadian Society of Petroleum Geologists, p. 913-932.

Amsden, T.W., and Klapper, G., 1972, Misener Sandstone (Middle-Upper Devonian), north-central Oklahoma: American Association of Petroleum Geologists Bulletin, v. 56, no. 12, p. 2323-2334.

Anderson, K.H., and Wells, J.S., 1968, Forest City Basin of Missouri, Kansas, Nebraska, and Iowa: American Association of Petroleum Geologists Bulletin, v. 52, no. 2, p. 264-281.

Arbenz, J.K., 1989, The Ouachita system, in Balley A.W., and Palmer, A.R. eds., The geology of North America: Geological Society of America, v. A., p. 371-396.

Arkoma Basin Province Assessment Team, 2010, Assessment of undiscovered natural gas resources of the Arkoma Basin Province and geologically related areas: U.S. Geological Survey Fact Sheet 20103043, 4 p., http://pubs.usgs.gov/fs/2010/3043/pdf/FS10-3043.pdf.

Barrett, Ed, 1963, The geologic history of Oklahoma-An outline-Oil and gas fields of Oklahoma: Oklahoma Geological Survey Reference Report, v. 1, 195 p. 
Behrendt, J.C., Green A.G., Cannon, V.F., Hutchinson, D.R., Lee, M.V., Milkereit, B., Agena, V.F., and Spencer, C., 1988, Crustal structure and deep rift basin of the midcontinent rift system - Results from GLIMPCE deep seismic reflection profiles: Geology, v. 16, p. 81-85.

Blakey, Ron, 2011, Paleogeography: Flagstaff, Ariz., Department of Geology, Northern Arizona University, accessed February 15, 2012, at http://www2.nau.edu/rcb7/index.html.

Blondes, M.S., Brennan, S.T., Merrill, M.D., Buursink, M.L., Warwick, P.D., Cahan, S.M., Cook, T.A., Corum, M.D., Craddock, W.H., DeVera, C.A., Drake, R.M., Drew, L.J., Freeman, P.A., Lohr, C.D., Olea, R.A., Roberts-Ashby, T.L., Slucher, E.R., and Varela, B.A., 2013, National assessment of geologic carbon dioxide storage resources-Methodology implementation: U.S. Geological Survey Open-File Report 2013-1055, 26 p, http://pubs.usgs.gov/of/2013/1055/.

Boyd, D.T., 2002, Map of Oklahoma oil and gas production by reservoir age: Norman, Okla., Geo Information Systems Geologic Map 38, accessed at http://www.ogs.ou.edu/fossilfuels/MAPS/GM38.pdf.

Breit, G.N., 2002, Produced waters database: U.S. Geological Survey online database, accessed January 19, 2011, at http://energy.cr.usgs.gov/prov/prodwat/.

Brennan, S.T., Burruss, R.C., Merrill, M.D., Freeman, P.A., and Ruppert, L.F., 2010, A probabilistic assessment methodology for the evaluation of geologic carbon dioxide storage: U.S. Geological Survey Open-File Report 2010-1127, 31 p., http://pubs.usgs.gov/of/2010/1127/.

Burruss, R.C., Brennan, S.T., Freeman, P.A., Merrill, M.D., Ruppert, L.F., Becker, M.F., Herkelrath, W.N., Kharaka, Y.K., Neuzil, C.E., Swanson, S.M., Cook, T.A., Klett, T.R., Nelson, P.H., and Schenk, C.J., 2009, Development of a probabilistic assessment methodology for evaluation of carbon dioxide storage: U.S. Geological Survey Open-File Report 2009-1035, 81 p., http://pubs.usgs.gov/of/2009/1035/.

Busanus, J.W., 1987, The Misener strike-valley sandstone reservoir, Grant and Garfield Counties, Oklahoma, in Rascoe, Bailey, Jr., and Hyne, N.J., eds., Petroleum geology of the mid-continent: Tulsa, Okla., Tulsa Geological Society Special Publication No. 3, p. 61-66.

Buursink, M.L., 2012, Reservoir pressure and temperature regimes in sedimentary basins and the geologic carbon-dioxide sequestration resource [abs]: American Association of Petroleum Geologists Search and Discovery Article \#90142, Annual Convention and Exhibition, Long Beach, California, April 22-25, 2012, available at http://www.searchanddiscovery.com/abstracts/html/2012/90142ace/abstracts/buu.htm.

Campbell, J.A. 1993, Lower Paleozoic fault blocks-Arkoma Basin, Oklahoma and Arkansas, in Bebout, D.G., White, W.A., Hentz, T.F., and Grasmick, M.K., eds., Atlas of major midcontinent gas reservoirs: Austin, Texas Bureau of Economic Geology, Gas Research Institute, p. 77-79.

Cannon, W.F., Green, A.G., Hutchinson, D.R., Lee, Myung, Milkereit, Bernd, Behrendt, J.C., Halls, H.C., Green, J.C., Dickas, A.B., Morey, G.B., Sutcliffe, Richard, and Spencer, C., 1989, The North American midcontinent rift beneath Lake Superior from GLIMPCE seismic reflection profiling: Tectonics, v. 8, no. 2, p. 305-332.

Carr, J.E., McGovern, H.E., and Gogel, T., 1986, Geohydrology of and potential for fluid disposal in the Arbuckle aquifer in Kansas: U.S. Geological Survey Open-File Report 86-491, 101 p.

Carr, T.R., Merriam, D.F., and Bartley, J.D., 2005, Use of relational databases to evaluate regional petroleum accumulation, groundwater flow, and $\mathrm{CO}_{2}$ sequestration in Kansas: American Association of Petroleum Geologists Bulletin, v. 89, no. 12, p. 1607-1627.

Chandler, V.W., McSwiggen, P.L., Morey, G.B., Hinze, W.J., and Anderson, R.R., 1989, Interpretation of seismic reflection, gravity, and magnetic data across Middle Proterozoic mid-continent rift system, northwestern Wisconsin, eastern Minnesota, and central Iowa: American Association of Petroleum Geologists Bulletin, v. 73, no. 3, p. 261-275.

Charpentier, R.R., 1995a, Forest City Basin Province (056), in Gautier, D.L., Dolton, G.L., Takahashi, K.I., and Varnes, K.L., eds., 1995 National assessment of United States oil and gas resources-Results, 
methodology, and supporting data: U.S. Geological Survey Digital Data Series DDS-30, 8 p., release 2, [CD-ROM], http://certmapper.cr.usgs.gov/data/noga95/prov56/text/prov56.pdf.

Charpentier, R.R. 1995b, Nemaha Uplift Province (055), in Gautier, D.L., Dolton, G.L., Takahashi, K.I., and Varnes, K.L., eds., 1995 National assessment of United States oil and gas resources-Results, methodology, and supporting data: U.S. Geological Survey Digital Data Series DDS-30, 12 p., release 2, [CD-ROM], http://certmapper.cr.usgs.gov/data/noga95/prov56/text/prov55.pdf.

Charpentier, R.R., 1995c, Cherokee Platform Province (060), in Gautier, D.L., Dolton, G.L., Takahashi, K.I., and Varnes, K.L., eds., 1995 National assessment of United States oil and gas resources-Results, methodology, and supporting data: U.S. Geological Survey Digital Data Series DDS-30, 13 p., release 2, [CD-ROM], http://certmapper.cr.usgs.gov/data/noga95/prov56/text/prov60.pdf.

Ching, B.Y., and Friedman, G.M., 2000, Subsurface Arbuckle Group (Cambro-Ordovician) in the Bowman no. 4 well of the Wilburton field in the Arkoma Basin, Oklahoma-Depositional facies, diagenetic signatures, petrophysical aspects, and economic potential: Carbonates and Evaporites, v. 15, no. 1, p. 49-80.

Cleaves, A.W., and Bat, D.T., 1988, Terrigenous clastic facies distribution and sandstone diagenesis, subsurface Lewis and Evan format units (Chester Series), on the northern shelf of the Black Warrior: Gulf Coast Association of Geological Societies Transactions, v. 38, p. 177-186.

Cole, V.B., 1975, Subsurface Ordovician-Cambrian rocks in Kansas, with maps showing thickness of potentially oil-bearing rocks: Kansas Geological Survey Subsurface Geology Series 2, 18 p., 4 pls.

Coleman, J.L., Jr., and Cahan, S.M., 2012, Preliminary catalog of the sedimentary basins of the United States: U.S. Geological Survey Open-File Report 2012-1111, 27 p. (plus 4 figures and 1 table available as separate files), http://pubs.usgs.gov/of/2012/1111/.

Conant, L.C., and Swanson, V.E., 1961, Chattanooga Shale and related rocks of central Tennessee and nearby areas: U.S. Geological Survey Professional Paper 357, 91 p.

DeCelles, P.G., and Giles, K.A., 1996, Foreland basin systems: Basin Research, v. 8, p. 105-123.

Dickas, A.B., 1986, Comparative Precambrian stratigraphy and structure along the mid-continent rift: American Association of Petroleum Geologists Bulletin, v. 70, no. 3, p. 225-238.

Dolton, G.L., and Finn, T.M., 1989, Petroleum geology of the Nemaha uplift, central mid-continent: U.S. Geological Survey Open-File Report 88-450-D, 39 p.

Edmund, R.W., and Goebel, E.D., 1968, Subsurface waste-disposal potential in Salina Basin of Kansas: American Association of Petroleum Geologists Memoir No. 10, p. 154-164.

England, R.L., 1964, Subsurface study of the Hunton Group (Silurian-Devonian) in the Oklahoma portion of the Arkoma Basin: The Shale Shaker Digest IV, v. 14, p. 19-35.

Ettensohn, F.R., 1995, Global and regional controls on the origin and burial of organic matter in Devonian-Mississippian black shales of North America: Houston Geological Society Bulletin, v. 37, no. 5, p. 12-17.

Evans, J.L., 1984, The future hydrocarbon potential of the Viola Limestone in Oklahoma, in Borger, J.G., II, ed., Technical Proceedings of the 1981 American Association of Petroleum Geologists MidContinent Regional Meeting, September 20-21, 1981: Oklahoma City, Okla., Oklahoma City Geological Society, p. 119-126.

Evans, J.L., 1987, Major structural features of the Anadarko Basin, in Rascoe, B., Jr., and Hyne, N.J., eds., Tulsa Geological Society Special Publication No. 3: Petroleum Geology of the Mid-Continent, p. 6-9.

Fabian, R.S., 1984, Relation of biofacies to lithofacies in interpreting depositional environments in the Pitkin Limestone (Mississippian) in northeastern Oklahoma (Part 1): The Shale Shaker Digest XII, v. 36-39, p. 113-132.

Francis, B.M., II, 1991, Petrology and sedimentology of the Devonian Misener Formation, northcentral Oklahoma: The Shale Shaker Digest VIII, p. 49-66. 
Franseen, E.K., Byrnes, A.P., Cansler, J.R., Steinhauff, D.M., and Carr, T.R., 2004, The geology of Kansas-Arbuckle Group: Kansas Geological Survey Current Research in Earth Sciences Bulletin 250, part 2, $43 \mathrm{p}$.

Fritz, R.D., and Medlock, P.L., 1994, Sequence stratigraphy of the Hunton Group as defined by core, outcrop, and log data, in Johnson, K.S., ed., Hunton Group core workshop and field trip: Oklahoma Geological Society Special Publication 93, p. 161-180.

Fritz, R.D., and Medlock, P.L., 1995, Recognition of unconformities and sequences in mid-continent carbonates, in Hyne, N.J., ed., Sequence stratigraphy of the mid-continent: Tulsa Geological Society Special Publication No. 4, p. 49-80.

Gautier, D.L., Dolton, G.L., Takahashi, K.I., and Varnes, K.L., eds., 1995, 1995 National assessment of United States oil and gas resources-Results, methodology, and supporting data: U.S. Geological Survey Digital Data Series DDS-30, Release 2, [CD-ROM].

Ham, W.E., ed., 1973, Regional geology of the Arbuckle Mountains, Oklahoma, The Geological Society of America Annual Meeting, Dallas, Tex., November 10-11, 1973: Oklahoma Geological Survey Guidebook for Field Trip No. 5, 56 p.

Handford, C.R., 1995, Baselap patterns and the recognition of lowstand exposure and drowning-A Mississippian-ramp example and its seismic signature: Journal of Sedimentary Research, v. B65, p. 323-337.

Hart, D.J., and LaMaskin, T., 2011, Wisconsin's mid-continent rift sediments - Introduction to porosity and permeability: Wisconsin Geological and Natural History Survey, accessed October 20, 2011, at http://www.uwex.edu/wgnhs/rift_porosity_permeability/rift_porosity_permeability_intro.htm.

Henry, M.E., and Hester, T.C., 1995, Southern Oklahoma Province (061), in Gautier, D.L., Dolton, G.L., Takahashi, K.I., and Varnes, K.L., eds., 1995 National assessment of United States oil and gas resources - Results, methodology, and supporting data: U.S. Geological Survey Digital Data Series DDS-30, 24 p., Release 2, [CD-ROM], http://certmapper.cr.usgs.gov/data/noga95/prov61/text/prov61.pdf.

Hester, T.C., Schmoker, J.W., and Sahl, H.L., 1990, Log-derived regional source-rock characteristics of the Woodford Shale, Anadarko Basin, Oklahoma: U.S. Geological Survey Bulletin 1866-D, 38 p.

Higley, D.K., 1987, Central Kansas Uplift-Cambridge Arch Province oil and gas play summary: U.S. Geological Survey Open-File Report 87-450-E, 16 p.

Holden, F.T., 1965, The Simpson Group of the Arkoma Basin, Oklahoma and Arkansas: Tulsa Geological Society Digest, v. 33, p. 134-143.

Houseknecht, D.W., 1986, Evolution from passive margin to foreland basin-The Atoka Formation of the Arkoma Basin, south-central U.S.A.: Special Publications of the International Association of Sedimentologists, v. 8, p. 327-345.

Houseknecht, D.W., 1987, The Atoka Formation of the Arkoma Basin-Tectonics, sedimentology, thermal maturity, sandstone petrology: Tulsa Geological Society Short Course Notes, 72 p.

Huber, N.K., 1975, The geologic story of Isle Royale National Park: United States Geological Survey Bulletin 1309, 66 p.

Huffman, G.G., 1959, Preliminary isopachous and paleogeologic studies, central mid-continent area: The Shale Shaker Digest III, v. 9-11, p. 109-123.

I Energy Group, 2010 [includes data current as of December 23, 2009], PIDM (Petroleum Information Data Model) relational U.S. well data: I Energy Group, database available from I Energy Group, 15 Inverness Way East, D205, Englewood, CO 80112, U.S.A.

I Energy Group, 2011, ENERDEQ U.S. well data: I Energy Group, online database available from I Energy Group, 15 Inverness Way East, D205, Englewood, CO 80112, U.S.A. (accessed January 20, 2011).

Isom, J.W., 1976, Subsurface stratigraphic analysis, Late Ordovician to Early Mississippian, OakdaleCampbell trend, Woods, Major, and Woodward Counties, Oklahoma: The Shale Shaker Digest, v. 8, p. 116-132. 
Johnson, K.S., ed., 1997, Simpson and Viola Groups in the southern midcontinent: Symposium Proceedings, March 29-30, 1994, Norman, Okla., Oklahoma Geological Survey Circular 99, 275 p.

Johnson, K.S., and Merriam, D.F., eds., 2001, Petroleum systems of sedimentary basins in the southern midcontinent: Symposium Proceedings, March 28-29, 2000, Oklahoma City, Okla., Oklahoma Geological Survey Circular 106, 198 p.

Jones, C.L., 1960, An isopach, structural and paleogeologic study of pre-Desmoinesian units in north central Oklahoma: The Shale Shaker Digest III, v. 9-11, p. 216-223.

Jorgensen, D.G., Helgesen, J.O, and Imes, J.L., 1993, Regional aquifers in Kansas, Nebraska, and parts of Arkansas, Colorado, Missouri, New Mexico, Oklahoma, South Dakota, Texas, and WyomingGeohydrologic framework: U.S. Geological Survey Professional Paper 1414-B, 72 p.

Kansas Geological Survey, 2012, Top ten lists-Oil and gas production: Kansas Geological Survey Web site, accessed February 15, 2012, at http://www.kgs.ku.edu/PRS/Info/topTen.html.

Kunsman, H.S., 1967, Hunton oil and gas fields, Arkansas, Oklahoma, and panhandle Texas: Tulsa Geological Society Digest, v. 35, p. 165-197.

Kuykendall, M.D., and Fritz, R.D., 2001, Misener Sandstone of Oklahoma: American Association of Petroleum Geologists Search and Discovery Article no. 10018, in Johnson, K.S., ed., Hunton Group core workshop and field trip: Oklahoma Geological Survey Special Publication 93-4, p. 117-134.

Lane, C.W., and Miller, D.E., 1965, Geohydrology of Sedgwick County, Kansas: Kansas Geological Survey Bulletin 176, 14 p.

Latham, J.W., 1968, Petroleum geology of Arbuckle Group (Ordovician), Healdton field, Carter County, Oklahoma: The American Association of Petroleum Geologists Bulletin, v. 52, no. 1, p. 3-20.

Lee, Wallace, 1956, Stratigraphy and structural development of the Salina Basin area: Kansas Geological Survey Bulletin 121, 167 p.

Lee, Wallace, Grohskopf, J.G., Greene, F.C., Hershey, H.G., Harris, E., Jr., and Reed, E.C., 1946, Structural development of the Forest City Basin of Missouri, Kansas, Iowa, and Nebraska: U.S. Geological Survey Oil and Gas Investigation Map No. 48, scale 1:76,020.

Lee, Wallace, Leatherock, Constance, and Botinelly, Theodore, 1948, The stratigraphy and structural development of the Salina Basin of Kansas: Lawrence, University of Kansas Publications, Kansas Geological Survey Bulletin 74, 155 p.

Lillie, R.J., Nelson, K.D., de Voogd, Beatrice, Brewer, J.A., Oliver, J.E., Brown, L.D., Kaufman, Sidney, and Viele, G.W., 1983, Crustal structure of Ouachita Mountains, Arkansas-A model based on integration of COCORP reflection profiles and regional geophysical data: American Association of Petroleum Geologists Bulletin, v. 67, no. 6, p. 907-931.

Lowe, D.R., 1985, Ouachita trough-Part of a Cambrian failed rift system: Geology, v. 13, p. 790-793.

Lowe, D.R., 1989, Stratigraphy, sedimentology, and depositional setting of pre-orogenic rocks of the Ouachita Mountains, Arkansas and Oklahoma, in Hatcher, R.D., Jr., Thomas, W.A., and Viele, G.W., eds., The Appalachian-Ouachita orogeny in the United States: Geological Society of America, The Geology of North America, v. F-2, p. 575-590.

Mairs, Tom, 1966, A subsurface study of the Fernvale and Viola Formations in the Oklahoma portion of the Arkoma Basin: Tulsa Geological Society Digest, v. 34, p. 60-81.

McSwiggen, P.L., Morey, G.B., and Chandler, V.W., 1987, New model of the midcontinent rift in eastern Minnesota and western Wisconsin: Tectonics, v. 6, no. 6, p. 677-685.

Merriam, D.F., 1963, The geologic history of Kansas: Kansas Geological Survey Bulletin 162, 317 p.

Miall, A.D., 2008, The southern midcontinent, Permian Basin, and Ouachitas: Sedimentary Basins of the World, v. 5, p. 297-327.

Nehring Associates, Inc., 2010 [data current as of December 2008], The significant oil and gas fields of the United States: Colorado Springs, Colo., Nehring Associates, Inc., database available from Nehring Associates, Inc., P.O. Box 1655, Colorado Springs, CO 80901, U.S.A. 
Nelson, K.D., Lillie, R.J., de Voogd, Beatrice, Brewer, J.A., Oliver, J.E., Kaufman, S., and Brown, L., 1982, COCORP seismic reflection profiling in the Ouachita Mountains of western Arkansas-

Geometry and geologic interpretations: Tectonics, v. 1, no. 5, p. 413-430.

Newell, K.D., and Hatch, J.R., 2000, A petroleum system for the Salina Basin in Kansas based on organic geochemistry and geologic analog: Natural Resources Research, v. 9, p. 169-200.

Newell, K.D., Doveton, J.H., and Lambert, M.W., 2001, Facies and petrophysical characteristics of the Chattanooga Shale and Misener Sandstone in central Kansas, in Johnson, K.S., ed., Silurian, Devonian, and Mississippian geology and petroleum in the southern midcontinent, 1999 symposium: Oklahoma Geological Survey Circular 105, p. 57-70.

Newell, K.D., Watney, W.L., Cheng, S.W.L., and Brownrigg, R.L., 1987, Stratigraphic and spatial distribution of oil and gas production in Kansas: Kansas Geological Survey Subsurface Geology Series 9, $86 \mathrm{p}$.

Northcutt, R.A., 1993, Siluro-Devonian shallow-marine carbonate-Anadarko Basin, Oklahoma, in Bebout, D.G., White, W.A., Hentz, T.F., and Grasmick, M.K., eds., Atlas of major midcontinent gas reservoirs: Texas Bureau of Economic Geology, p. 72-74.

Ogren, D.E., 1968, Stratigraphy of Upper Mississippian rocks of northern Arkansas: American Association of Petroleum Geologists Bulletin, v. 52, p. 282-294.

Ojakangas, R.W., Morey, G.B., and Green, J.C., 2001, The Mesoproterozoic midcontinent rift system, Lake Superior region, U.S.A.: Sedimentary Geology, v. 141-142, p. 421-442.

Palacas, J.G., 1995, Superior Province (051), in Gautier, D.L., Dolton, G.L., Takahashi, K.I., and Varnes, K.L., eds., 1995 National assessment of United States oil and gas resources - Results, methodology, and supporting data: U.S. Geological Survey Digital Data Series DDS-30, 9 p., Release 2, [CD-ROM], http://energy.cr.usgs.gov/oilgas/noga/index.htm.

Perry, W.L., 1995, Arkoma Basin Province (062), in Gautier, D.L., Dolton, G.L., Takahashi, K.I., and Varnes, K.L., eds., 1995 National assessment of United States oil and gas resources-Results, methodology, and supporting data: U.S. Geological Survey Digital Data Series DDS-30, 17 p., Release 2, [CD-ROM], http://certmapper.cr.usgs.gov/data/noga95/prov62/text/prov62.pdf.

Powers, R.B., ed., 1994, Petroleum exploration plays and resource estimates, 1989, onshore United States-Region 7, mid-continent: U.S. Geological Survey Open-File Report 94-24, 97 p.

Prensky, S.E., 1995, Salina Basin (054) and Sedgwick Basin (059) Provinces, in Gautier, D.L., Dolton, G.L., Takahashi, K.I., and Varnes, K.L., eds., 1995 National assessment of United States oil and gas resources - Results, methodology, and supporting data: U.S. Geological Survey Digital Data Series DDS-30, 6 p., Release 2, [CD-ROM], http://certmapper.cr.usgs.gov/data/noga95/prov54/text/prov54.pdf.

Puyear, J.A., and Mazzullo, S.J., 2009, Depositional and structural history of the Sedgwick Basin, southcentral Kansas in relation to petroleum entrapment, in $5^{\text {th }}$ Annual GRASP Symposium, Wichita, Kans., May 1, 2009: Wichita State University, p. 52-53.

Ramondetta, P.J., 1990, El Dorado-An old field with potential: Oil \& Gas Journal, v. 88, no. 13, p. 110117.

Ramos, V.A., Jordan, T.E., Allmendinger, R.W., Mpodozis, C., Kay, S.M., Cortés, J.M., and Palma, M., 1986, Paleozoic terranes of the central Argentine-Chilean Andes: Tectonics, v. 5, p. 855-880.

Rascoe, Bailey, Jr., and Hyne, N.J., eds., 1987, Petroleum geology of the mid-continent: Tulsa Geological Society Special Publication No. 3, 162 p.

Read, D.L., and Richmond, G.L., 1993, Geology and reservoir characteristics of the Arbuckle Brown zone in the Cottonwood Creek field, Carter County, Oklahoma, in Johnson, K.S., and Campbell, J.A., eds., Petroleum-reservoir geology in the southern midcontinent, 1991 Symposium: Oklahoma Geological Survey Circular 95, p. 113-125.

Rechlin, K.J., 2005, Reservoir quality of the Frisco Formation, Hunton Group, Seminole County, Oklahoma (part 1): Shale Shaker, v. 56, p. 163-174. 
Shannon, J.P., 1962, Hunton Group (Silurian-Devonian) and related strata in Oklahoma: American Association of Petroleum Geologists Bulletin, v. 46, no. 1, p. 1-29.

Sims, P.K., 1985, Precambrian basement map of the midcontinent region, U.S.A.: U.S. Geological Survey Open-File Map 85-0604, scale 1:1,000,000.

Statler, A.T., 1965, Stratigraphy of the Simpson Group in Oklahoma: Tulsa Geological Society Digest, v. 33, p. 162-211.

Sutherland, P.K., 1988, Late Mississippian and Pennsylvanian depositional history in the Arkoma Basin area, Oklahoma and Arkansas: Geological Society of America Bulletin, v. 100, p. 1787-1802.

Swanson, V.E., 1961, Geology and geochemistry of uranium in marine black shales-A review: U.S. Geological Survey Professional Paper 356-C, p. 67-112.

Sykes, Michael, 1997, Paleokarst characteristics of the surface and subsurface in the Viola Limestone

(Ordovician), Arbuckle Mountains, Oklahoma: The Shale Shaker, p. 107-121.

Taff, J.A., 1902, Atoka folio, Indian Territory: U.S. Geological Survey Folio 79, 15 p.

Thomas, W.A., 1977, Structural and stratigraphic continuity of the Ouachita and Appalachian Mountains, in Stone, C.G., ed., Symposium on the geology of the Ouachita Mountains, volume I: Arkansas Geological Commission, p. 9-24.

Thomas, W.A., 1991, The Appalachian-Ouachita rifted margin of southeastern North America:

Geological Society of America Bulletin, v. 103, p. 415-431.

Thomas, W.A., and Astini, R.A., 1999, Simple-shear conjugate rift margins of the Argentine Precordillera and the Ouachita embayment of Laurentia: Geological Society of America Bulletin, v. 111, p. 1069-1079.

Thorleifson, L.H., ed., 2008, Potential capacity for geologic carbon sequestration in the midcontinent rift system in Minnesota: Minnesota Geological Survey Open-File Report OFR-08-01, 138 p.

U.S. Environmental Protection Agency, 2009, Safe Drinking Water Act (SDWA): Washington, D.C., U.S. Environmental Protection Agency Web site, accessed January 14, 2009, at http://www.epa.gov/ogwdw/sdwa/index.html.

U.S. Environmental Protection Agency, 2010, Federal requirements under the underground injection control (UIC) for carbon dioxide $\left(\mathrm{CO}_{2}\right)$ geologic sequestration (GS) wells: Washington, D.C., U.S. Environmental Protection Agency Web site, accessed October 15, 2012, at http://water.epa.gov/type/groundwater/uic/class6/gsregulations.cfm.

Vanarsdale, R.B., and Schweig, E.S., III, 1990, Subsurface structure of the eastern Arkoma Basin: American Association of Petroleum Geologists Bulletin, v. 74, p. 1030-1037.

Van Schmus, W.R., and Hinze, W.J., 1985, The midcontinent rift system: Annual Review Earth Planet Science, v. 13, p. 345-383.

Viele, G.W., and Thomas, W.A., 1989, Tectonic synthesis of the Ouachita orogenic belt, in Hatcher, R.D., Jr., Thomas, W.A., and Viele, G.W., eds., The Appalachian-Ouachita orogeny in the United States:

Geological Society of America, The Geology of North America, v. F-2, p. 695-728.

Walters, R.F., 1958, Differential entrapment of oil and gas in Arbuckle dolomite of central Kansas: American Association of Petroleum Geologists Bulletin, v. 42, no. 9, p. 2133-2173.

Ye, Hongzhuan, Royden, Leigh, Burchfiel, Clark, and Schuepbach, Martin, 1996, Late Paleozoic deformation of interior North America - The greater Ancestral Rocky Mountains: American Association of Petroleum Geologists Bulletin, v. 80, no. 9, p. 1397-1492.

Ye, Liangmiao, and Kerr, Dennis, 2000, Sequence stratigraphy of the Middle Pennsylvanian Bartlesville Sandstone, northeastern Oklahoma-A case of an underfilled incised valley: American Association of Petroleum Geologists Bulletin, v. 84, p. 1185-1204.

Zeller, D.E., 1968, The stratigraphic succession in Kansas: Kansas Geological Survey Bulletin 189, 81 p. 